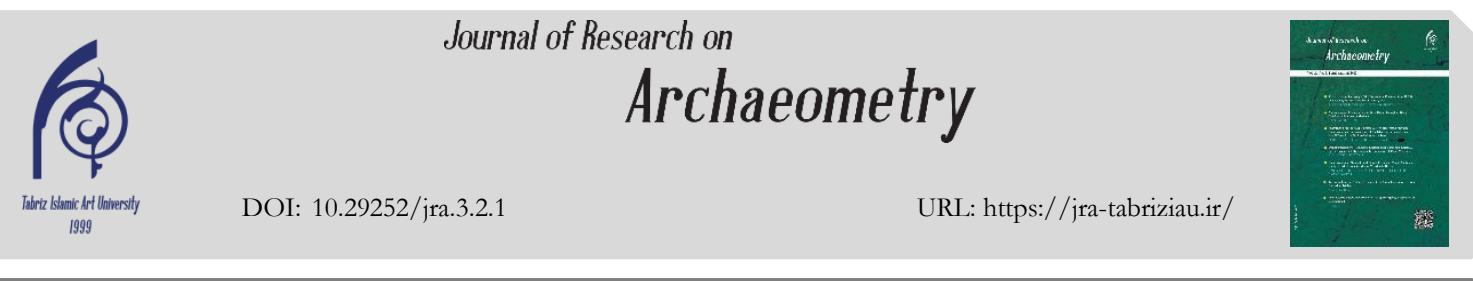

Original Paper

\title{
Chemical-Mineralogical Analyses of the Exquisite Pottery of Life Cycle from Prehistoric Cemetery of Keshik in Sistan and Baluchistan, Southeast Iran
}

\author{
Yasin Sedghi $^{\star 1}$, Akbar Abedi ${ }^{2}$, Mehdi Razani ${ }^{2}$, Mohammad Heydari ${ }^{3}$ \\ ${ }^{1}$ M.Sc. in Archaeometry, Faculty of Applied Arts, Tabriz Islamic Art University, Tabriz, IRAN \\ ${ }^{2}$ Assistant Professor, Faculty of Applied Arts, Tabriz Islamic Art University, Tabriz, IRAN \\ ${ }^{3}$ Archaeology Expert, Administration of Cultural Heritage of Sistan and Baluchistan, IRAN
}

Received: 04/03/2017

Accepted: 20/06/2017

\begin{abstract}
Notwithstanding the existence of such famous sites as Shar-i Sokhta from the Bronze Age, southeastern Iran represents a lacuna in Iranian archaeology. Chance discovery of the prehistoric, third millennium BC, site of Keshik in Nikshahr, Sistan and Baluchistan Province provides an opportunity to study new archaeological finds from this quarter of Iran. The main part of Keshik was a Bronze Age cemetery, which yielded important metal and ceramic objects, not to mention burial remains. The excavated assemblages included a distinct ceramic jar which warranted more detailed systematic observations by virtue of the symbolic motifs ornamenting its exterior surface. The jar has received the designation the Life Cycle because of these figurative designs arranged in six alternative panels which depict round the upper body of the vessel in a symbolic form the life cycle of a goat. The related panels show: 1) the figure of a goat native to Sistan, 2) the mating of goats, 3-5) the mother goat feeding her baby goat, which gradually grows up from the $3^{\text {rd }}$ to $5^{\text {th }}$ panel, and 6) the baby goat together with its mother. The major archaeological question with regard to this idiosyncratic vessel was its chemical-mineralogical characterization. Hence, a chip specimen was sampled to address such issues as its geological source, manufacturing techniques, firing and kiln conditions, local or foreign provenience, and the nature of pigments involved in the paint. To determine the crystalline constituents, different mineralo-chemical investigations were undertaken. The major phase compositions of the vessel's body as well as the pigments were determined using quantitative X-ray diffraction (QXRD), and scanning electron microscopy with energy dispersive Xray spectroscopy (SEM/EDX). Also, the the thin-section of the pottery was analyzed by optical microscopy techniques so as to petrographic identification of the minerals. The result of phase identification showed that the sample generally contains quartz, plagioclase, diopside, berlinite calcite, hematite, and enstatite as main crystalline phase constituents. Moreover, mineralo-chemical investigations demonstrated a regional alluvial soil origin related with the Keshik River, suggesting an indigenous provenience for the vessel. Further, the paste lacked any mineral variety. Firing in an oxidizing and reducing atmosphere was also evident given the carbon peaks and the poorly fired gray core of the thin-section. Analyses of the paint used in the decorative designs revealed the presence in the pigment of iron and manganese. The two elements were typically used because of their long-term sustainability and mineral base, and in combination with each other, they created a brown to black tone. In short, the study suggested that the so-called Life Circle jar was locally produced using the local clay on the potter's wheel, was fired at a temperature of $900-1000{ }^{\circ} \mathrm{C}$ in a closed oven under
\end{abstract}

${ }^{*}$ Corresponding author: yassinsedghi@gmail.com 
oxidizing and reducing conditions, and was decorated with a paint containing iron and manganese pigments.

Keywords: Life Cycle Jar, Characterization, Bronze Age, Keshik Cemetery in Sistan and Baluchistan, XRPD, SEM-EDX, OPM. 


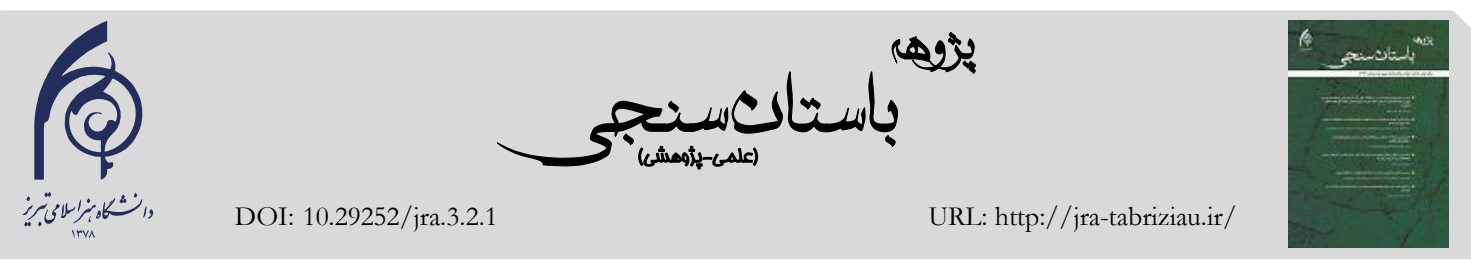

دمالم ِِرَوهشى

\section{ماختارشناسى خمرهى نويافتهى سفالى خرخلى زيستى}

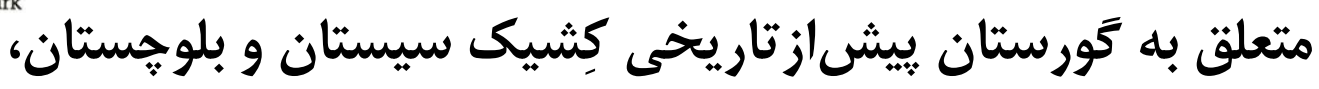

\section{جنوبشرق ايران}

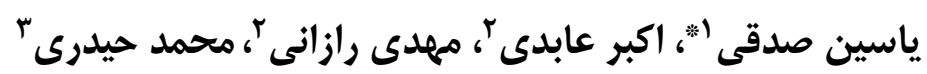

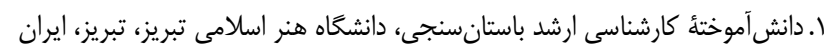

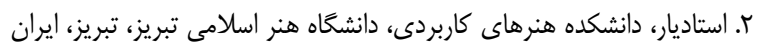

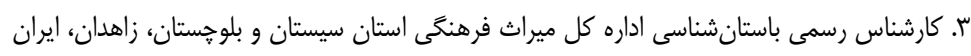

كشف اتفاقى محوطه يِشازتاريخى كشيك در شهرستان نيكشهر استان سيستان و بلوخستان منجر به شناسايى يك گورستان هـزاره

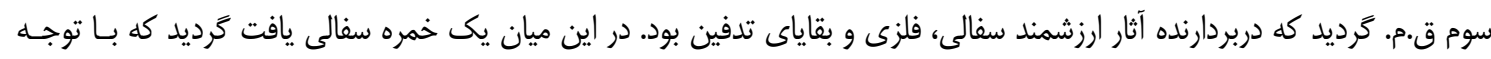

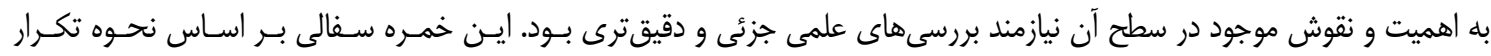

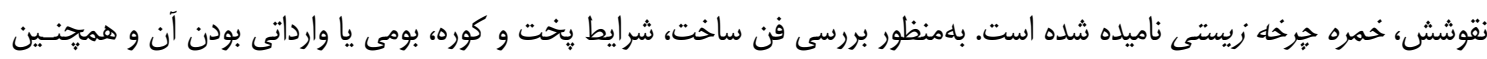

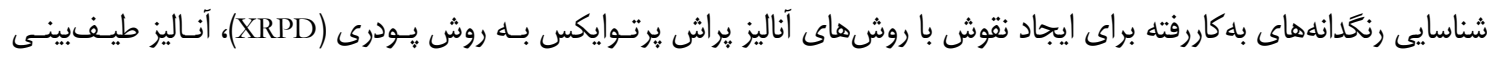

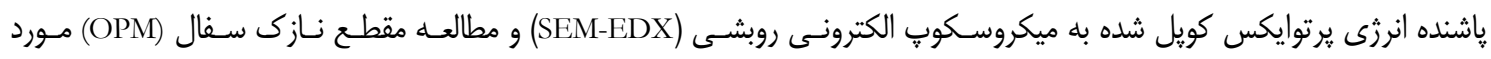

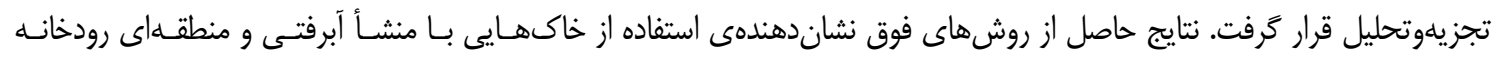

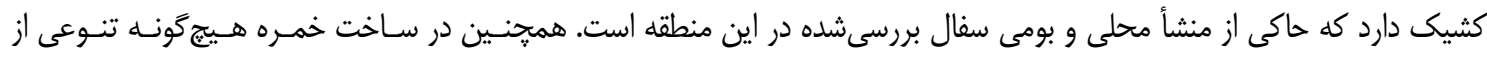

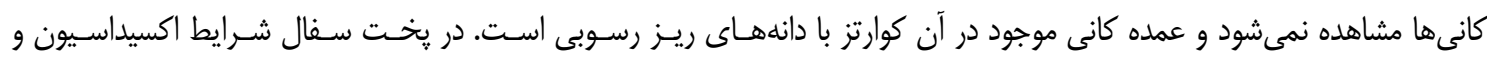

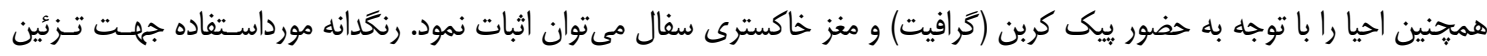

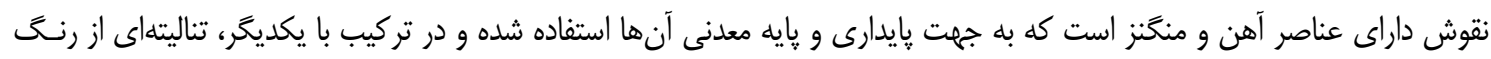
قهوهاى تا سياه را ايجاد مىنمايد.

وازَّان كليدى: خمره منسوب به خرخه زيستى، ساختارشناسى سـفال، كورسـتان كشـيك نيـكشهر بلوجسـتان، عصـر مفـرغ،

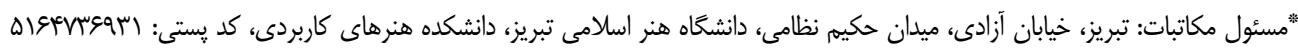

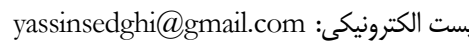

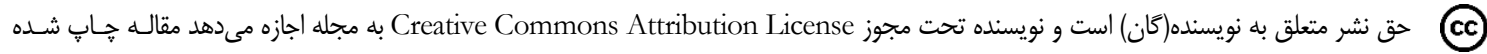
را با ديخران به اشتراك بكذارد منوط بر اينكه حقوق مؤلف اثر حفظ و به انتشار اوليه مقاله در اين مجله اشاره شود. 
باستانشناسى ايران از هزاره سـوم ق.م. در محوطـهـــاى شهر سوخته و كشيك در جنوب شرق ايران شروع شده و

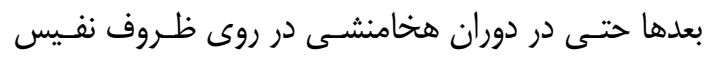

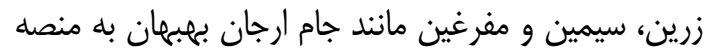
ظهور مىرسد[5]. كورستان يـيشازتـاريخى كشـيك واقـع در منطقـهـ كشيك شهرستان نيكشهر در كنارهى سد خير آباد (شكل دئ

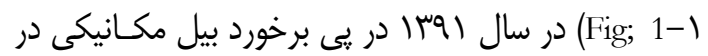

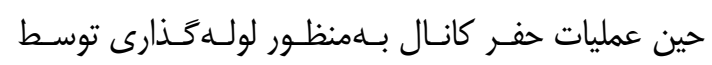
ييمانكار طرف قرارداد شـركت آب و فاضـلاب شهرسـتان

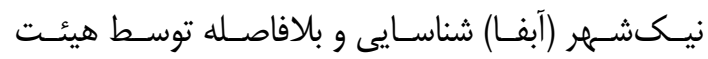

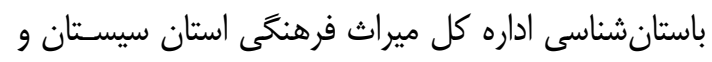

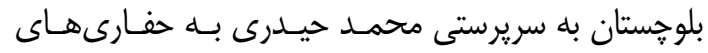

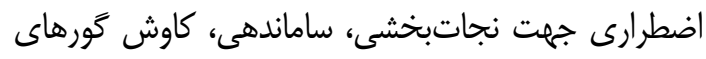

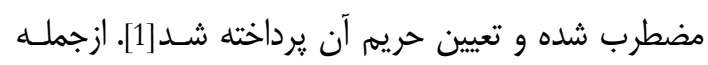
آثار قابلتوجهى كـه در بـين آثـار مكشـوفه از گَورسـتان

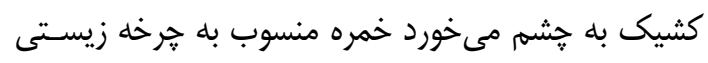

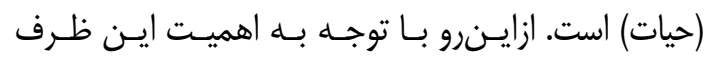

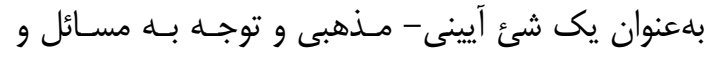

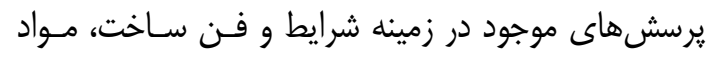

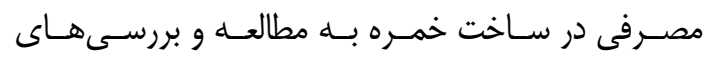
باستانسنجى يرداخته شده است كه در ادامه به تشـريح و و توضيح آنها يرداخته شده است.

\section{r. روش تحقيق}

تحقيـق حاضـر بـهـ روش تحليلـى تجربـى و بــر مبنـاى

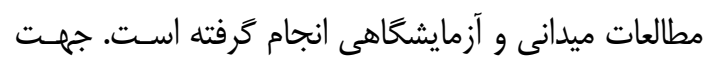

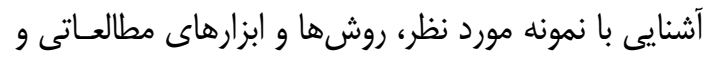

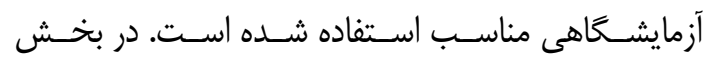

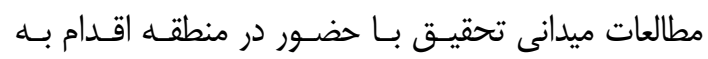

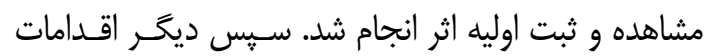

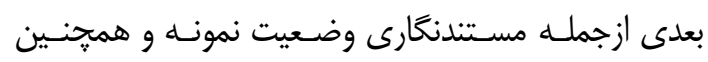

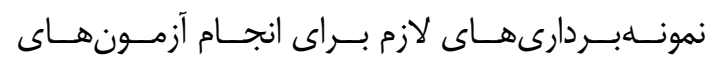

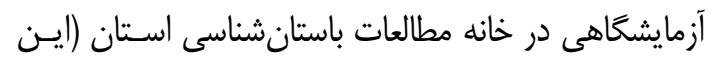

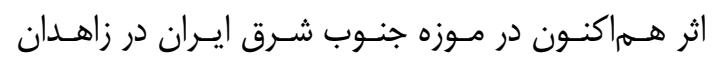

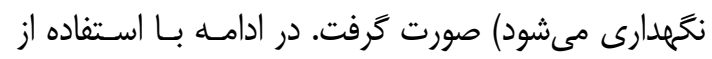

( ) - إ مقدمه

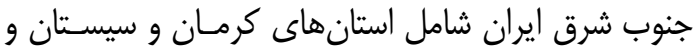

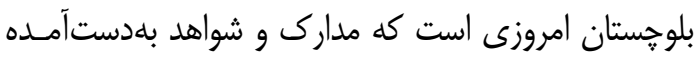

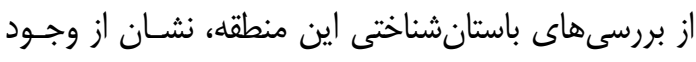

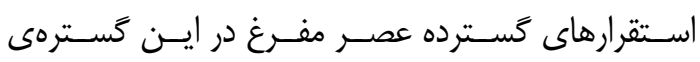

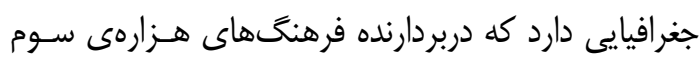

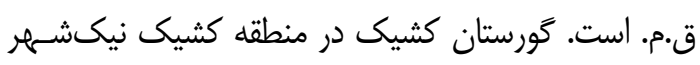
واقع در بلوجستان استان سيستان و بلوجِستان از ايـن امـر

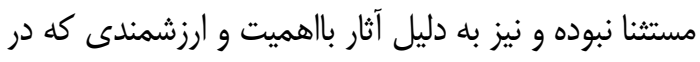

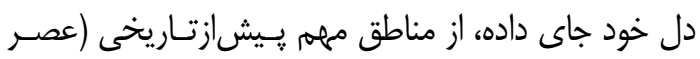
مفرغ) منطقه محسوب مىشود. سفال ازجمله فراوانتـرين

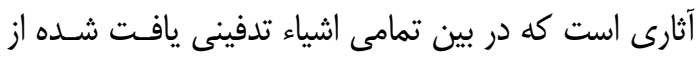

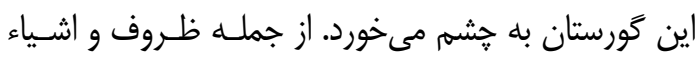

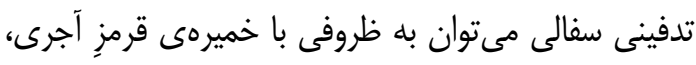

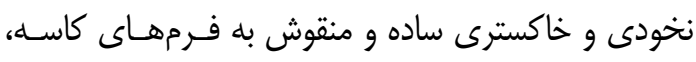

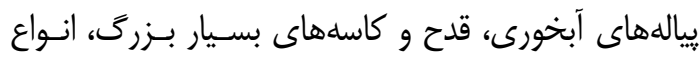

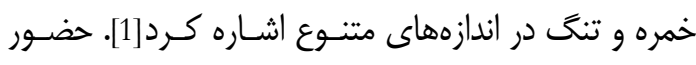

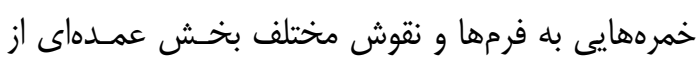

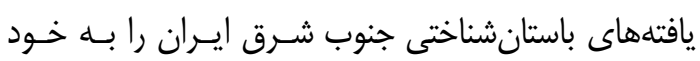

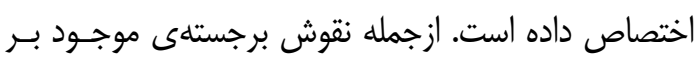
روى ظروف، نقش بز كوهى محلى منطقه بلوجستان است.

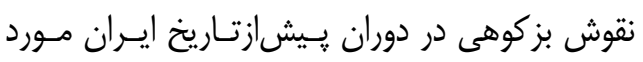

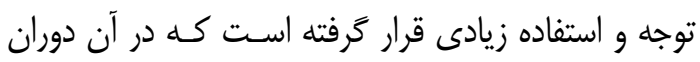

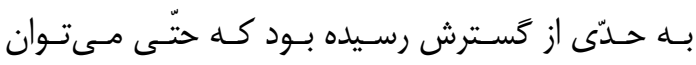

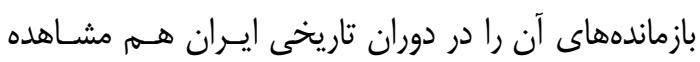
كرد[2]. بـىشك هويت نقوش جهاريايسان ايسران، متـأثر از

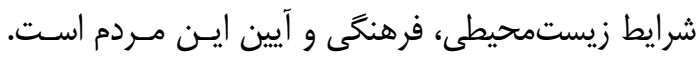

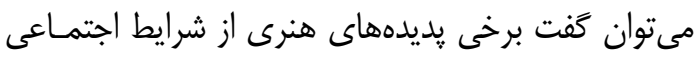

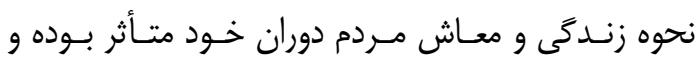

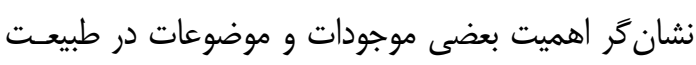

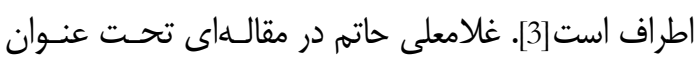

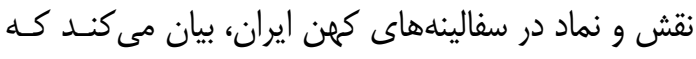

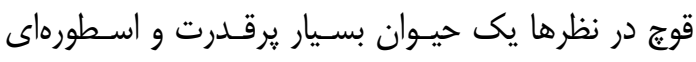

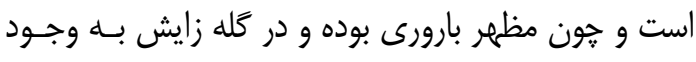

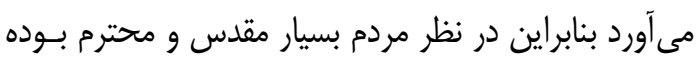

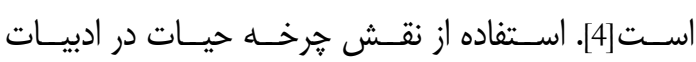


مىشود. و از طرف غرب به روسـتاهاى هيتـى (Hitak) و ساربوى (Sarbouk) و مجموع روستاهاى دهستان مهبـان دسترسى ييدا مى كند. محوطه باستانى كشيك يا كشـيگ (به معناى كنارهى رود) نام خود را از محلى به همـين نـام

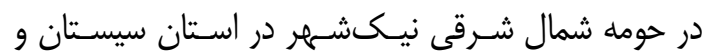

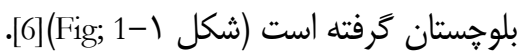

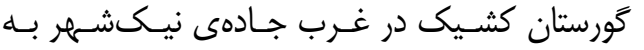
قصرقند و در ه/ ا كيلومترى روستاى كشـيك قـرار دارد و

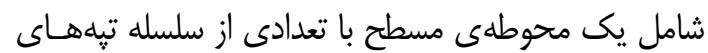

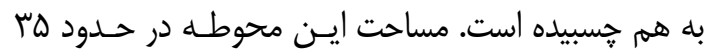

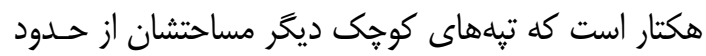

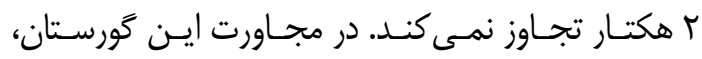

مطالعات يتروگرافـى مقطـع نـازك (OPM) و آنـاليزهـاى

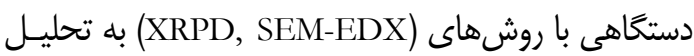
اطلاعات در رابطه با موضوع مـورد بحـث يرداختـه شـــه

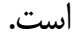

\section{س. تَورستان بيش/زتاريخى كثيك'}

روستاى كشيك، در شمال شرقى شهرستان نيكشهر، بـا فاصله \ \يلومترى از مركـز شهرسـتان واقـع اسـت. در قسمت جنوبى آن سد خير آباد قرار دارد و از طـرف شـمال

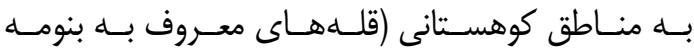
(Benoumeh) دسترسى به شهرستان نيكشهر از كشيك اسـت) وصـل

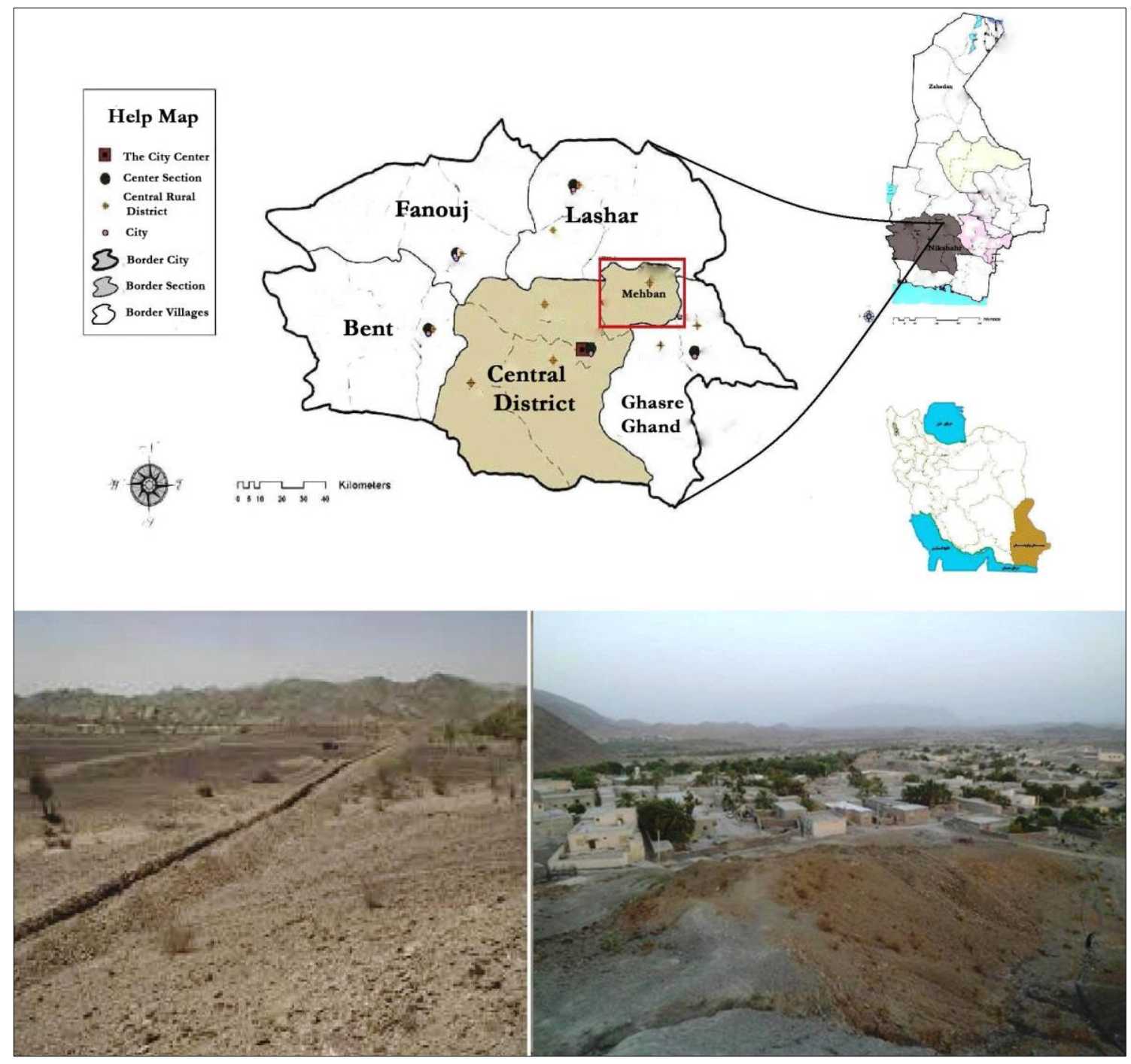

شكل ا: موقعيت كورستان كشيك بر روى نقشه جغرافيايى و منظر فرهنكى آن در كناره روستاى كشيك

Fig; 1: Location of Keshik Cemetery on the geographical map and its cultural landscape at the edge of Keshik village 
كاوشها نشان مىدهد كه در هزاره سوم ق.م. (دورههـاى

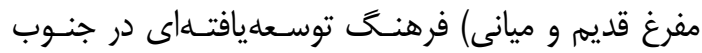

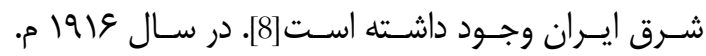

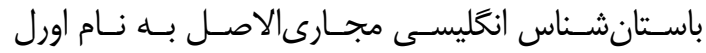

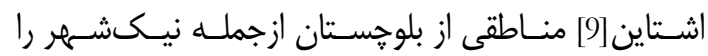

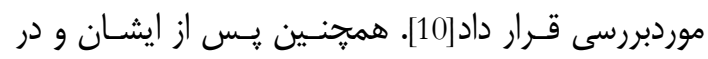

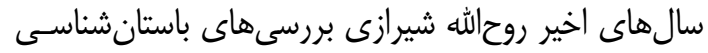

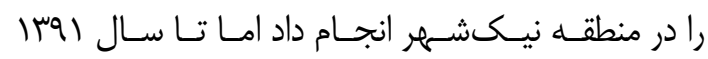

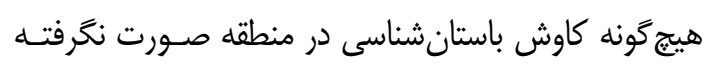
است. در خردادماه همين سال اداره كل ميـراث فرهنتحى دانس

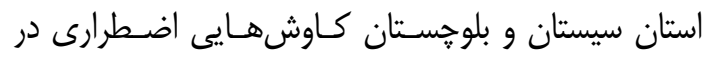
منطقه كشيك اين شهرستان انجـام داد كـهـ از آن جملــانه

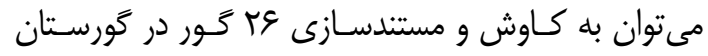
كشيك و شناسايى شش گورستان و محوطه نويافته ديخر

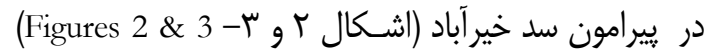

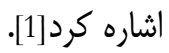

كورستان ديخرى بر فراز كـوهى نسـبتاً كـم ارتفـاع قـرار

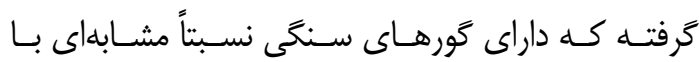

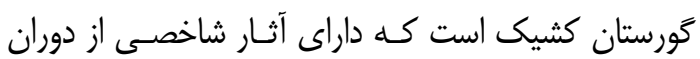

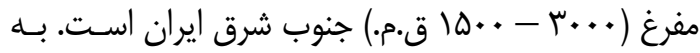

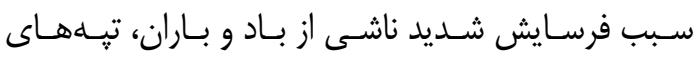

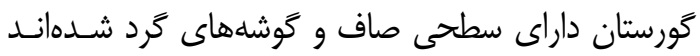
كه مىتوان آنها را بلهصورت ذوزنقه ناقصى مجسـم كرد

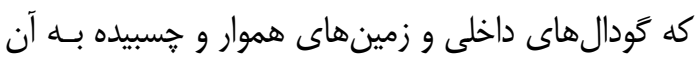

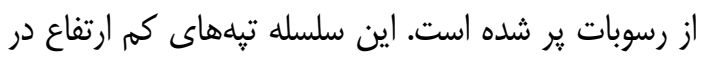
بالادست سد خير آبـاد واقع شـده (شـكل r Fig; 2 (Fig) و از مراكز مهم عصر مفـرغ شناسـايى شـــه در جنـوب شـرق

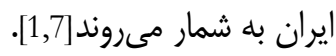
عمده كاوشهاى جنوب شرق ايران در محوطههـاى

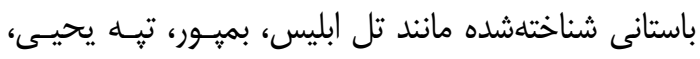

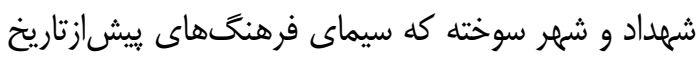

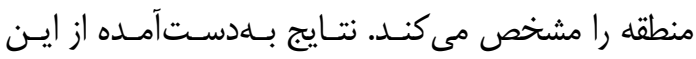

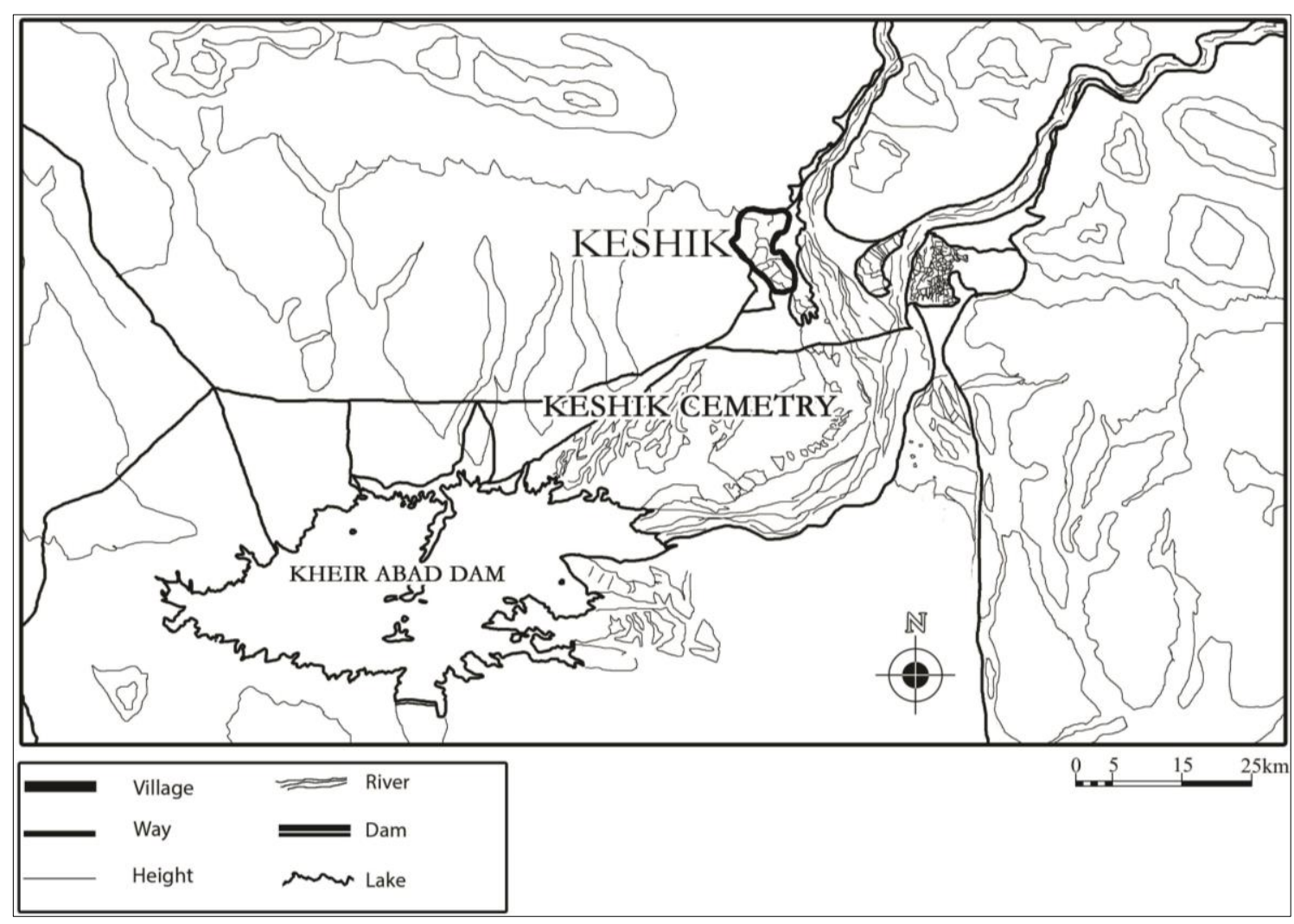

شكل ז: محدوده كورستان كشيك بر روى نقشه و موقعيت قراركيرى آن در كنار سد خير آباد

Fig; 2: Range of Keshik Cemetery on the map and its position next to the Kheirabad dam 


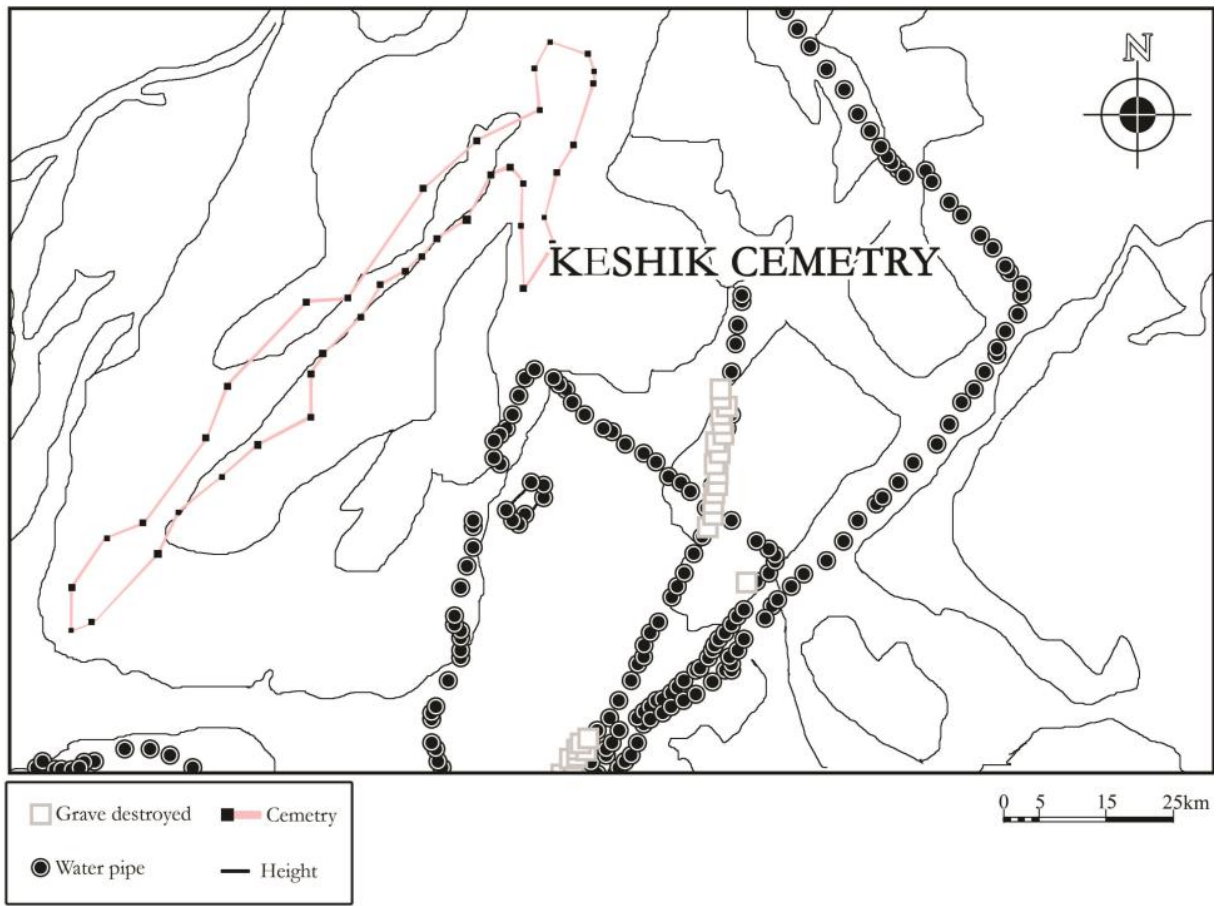

شكل "ا: نقشه گورستان كشيك و مسير خط لوله و قبور تخريبشده

Fig; 3: Map of Keshik Cemetery showing the pipeline route and destroyed graves

يايينتر اين منطقــه (ســ خيرآبـاد) داراى تنـاوب مـوزون

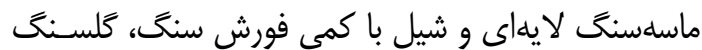
و كنگلومرا است. ناحيه ريخ در بالادست منطقه گورستان داراى تناوب موزون ماسهسنگ لايهاى و شيل، بـا كمسى

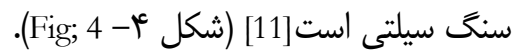

بر اساس زمـينشناسـى منطقـهـ گورسـتان كثـيك نيكشهر، اين منطقه در بادزنهـاى كوهيايسهاى كوتـاه و

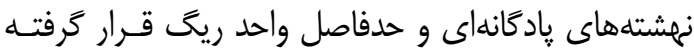
است كه بررسـى منطقـهـ نشـان از ماســهــــ، شـيل و

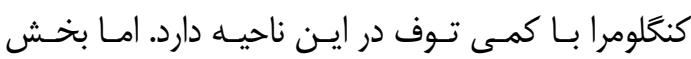
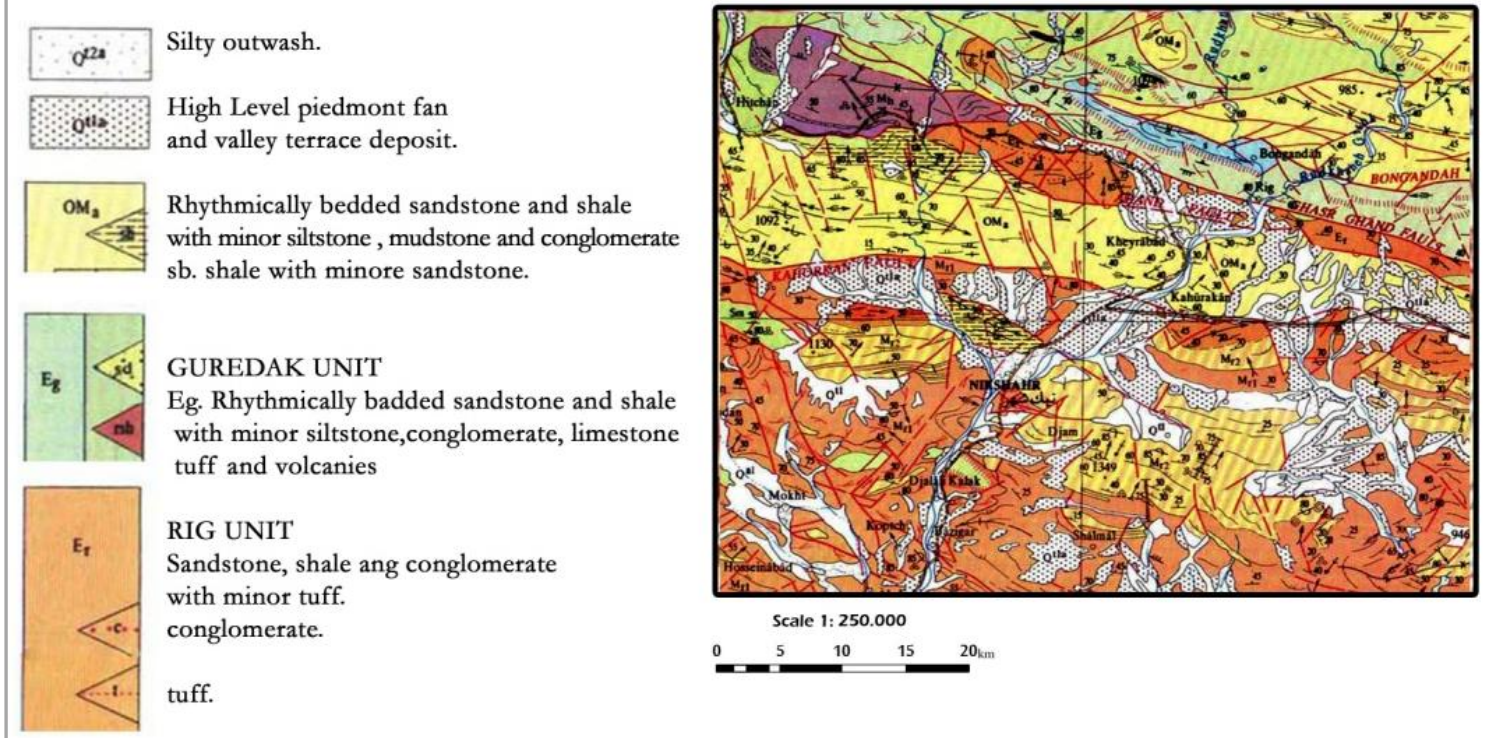

شكل أ: نقشه زمينشناسى منطقه كشيك، بازسازى و تدقيقشده[11]

Fig; 4: Reconstructed and refined geological map of Keshik region 
تخريب و آسيبهاى فراوانى ازجمله شكستـى و از بـين F أ. مواد و روش هاى آزمايشًاهى

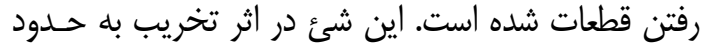
F

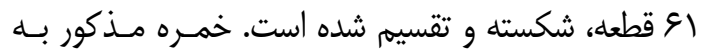

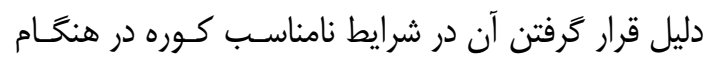

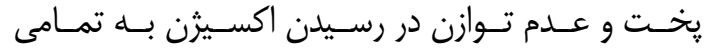

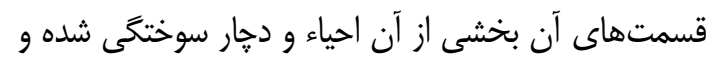

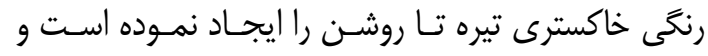

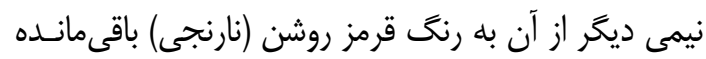

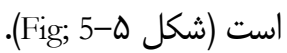

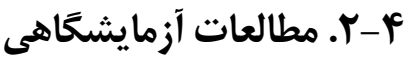

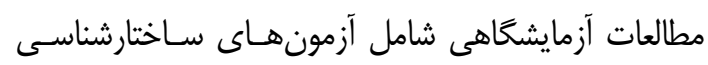

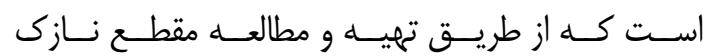

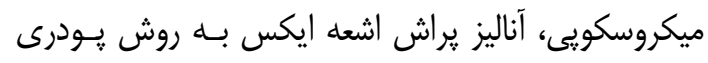

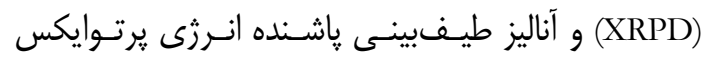

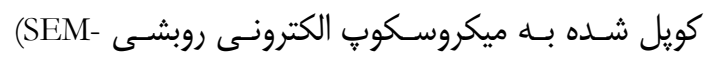

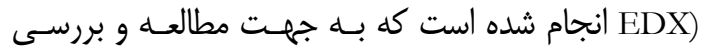

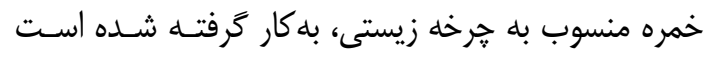

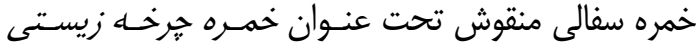

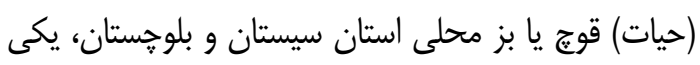

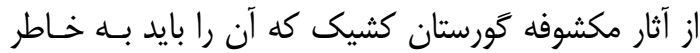
ويزگى هاى فنى و هنرى آن با تمامى آثار منطقـه متمـايز

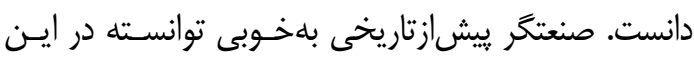

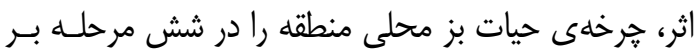
روى شكم خمرهى سفالى طراحى كند (شـكل ه-Fig;

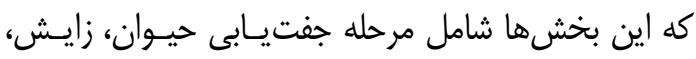
رشد و نمو و تغذيه از مادر تا رسيدن به مرحله بلوغ اسـت

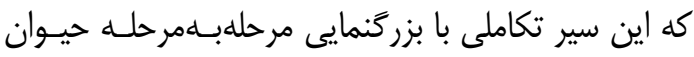

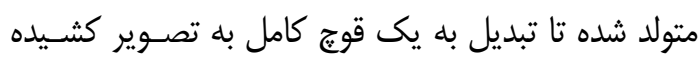

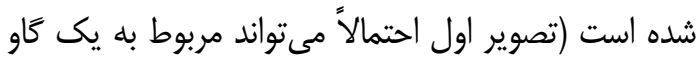

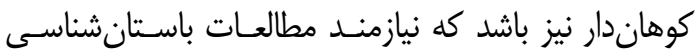

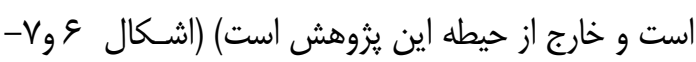

.(Figs; 6 \& 7

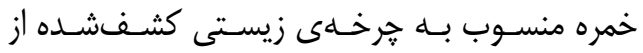

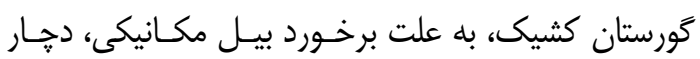

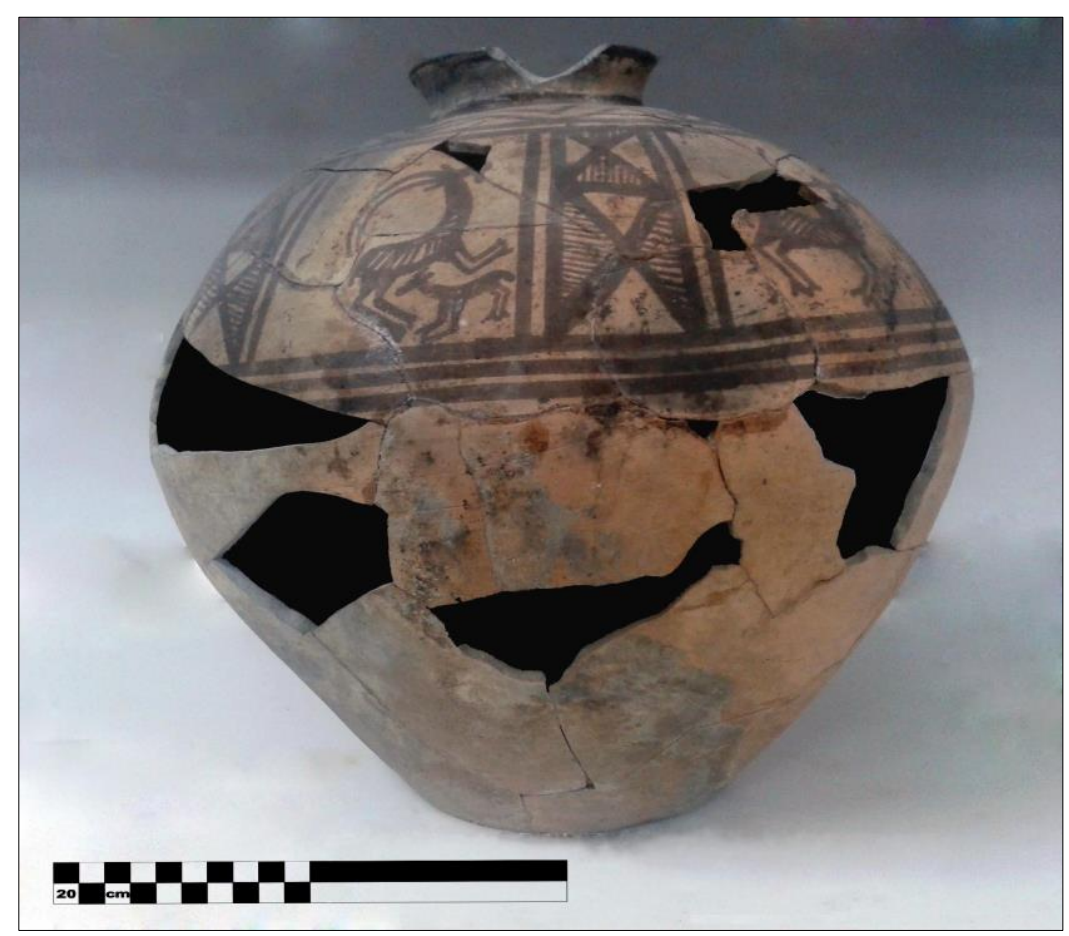

شكله: تصوير خمره منسوب به هرخهى زيستى از نماى روبرو

Fig; 5: The so-called Life Cycle Jar, front view

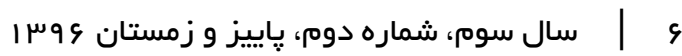




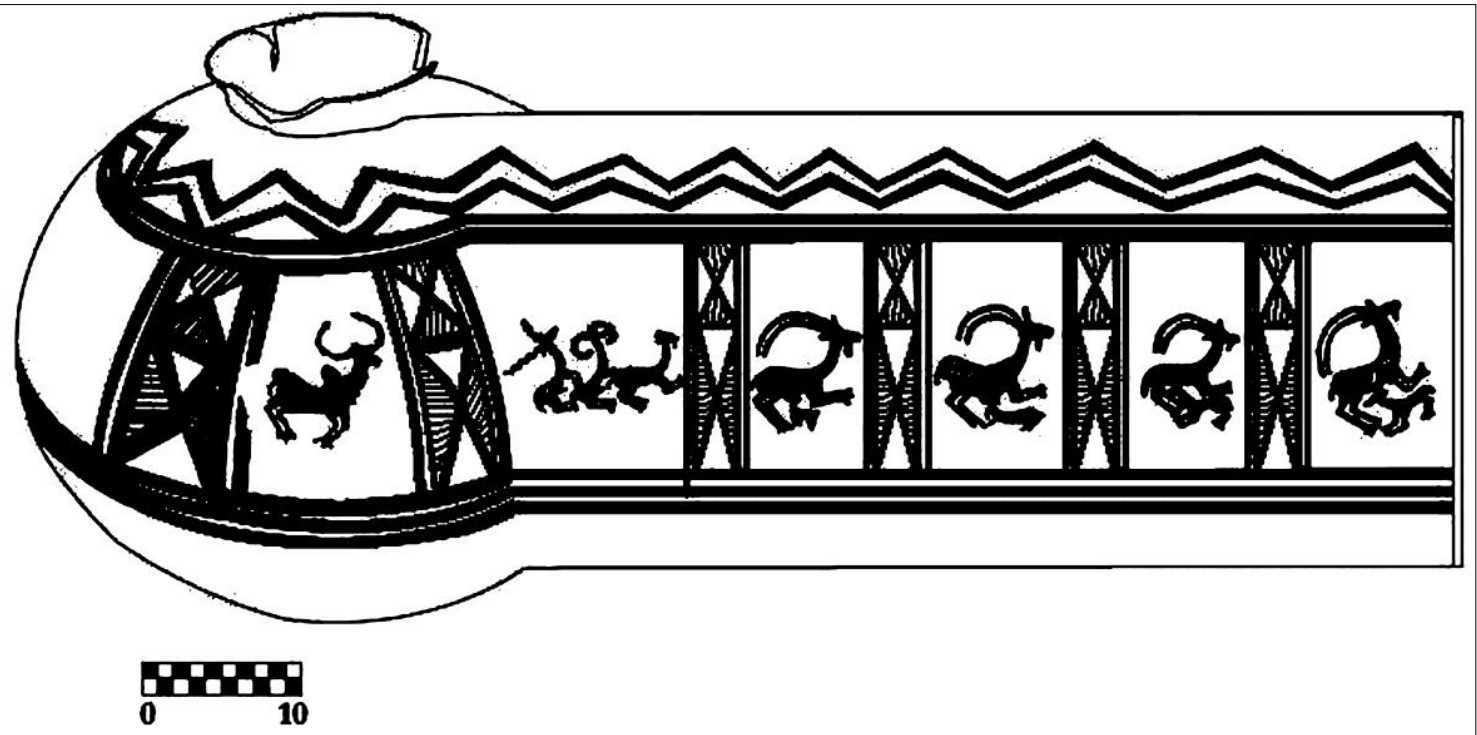

شكل \&: بازطراحى مراحل جرخه: مرحله جفتگيرى، زايش، رشد و نمو تا رسيدن به مرحله بلوغ

Fig; 6: Redesigning cycle stages: mating Stage, birth, growth and development to reach the maturity stage

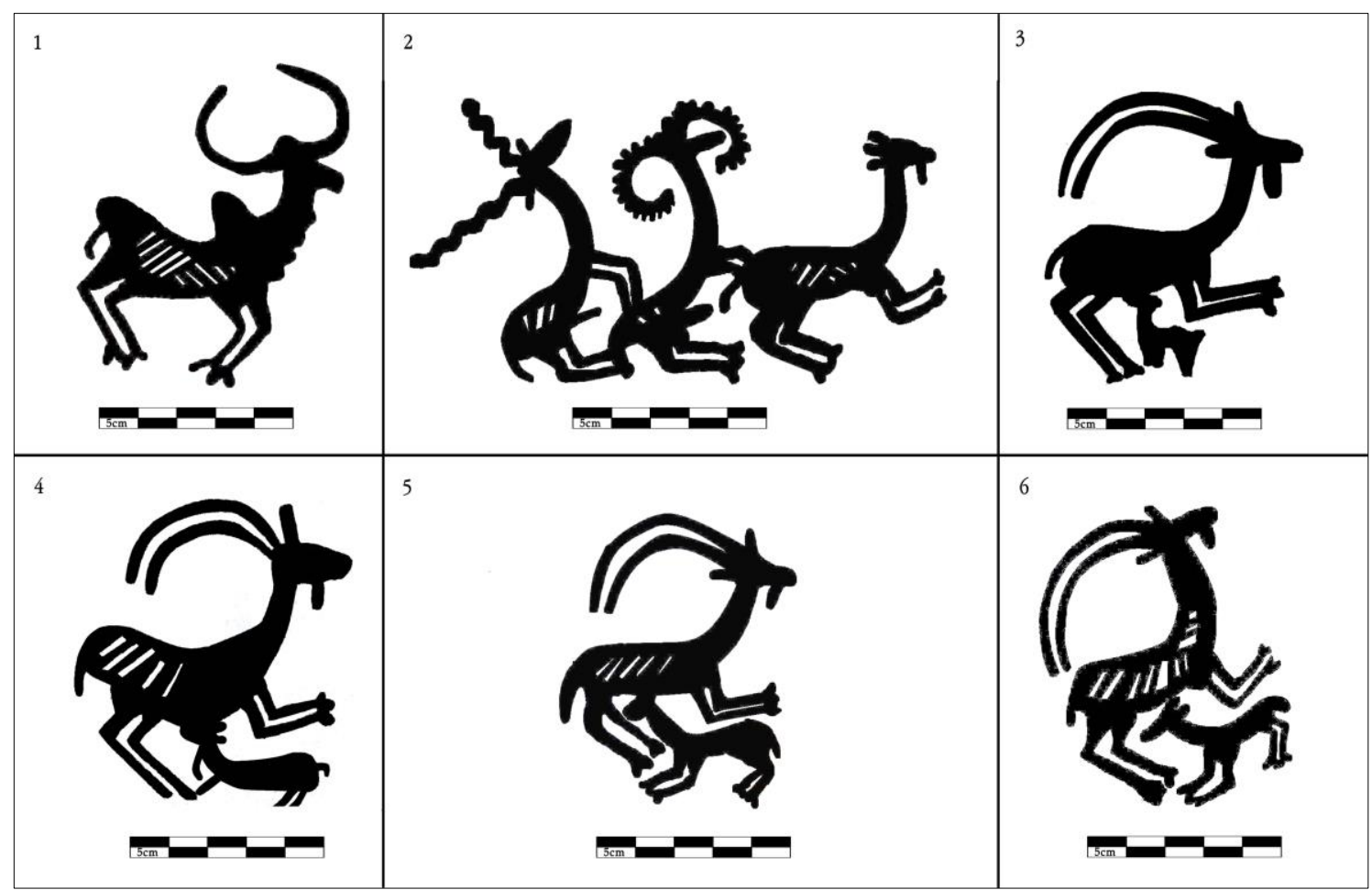

شكلV: بازطراحى مراحل هرخه: مرحله جفت گيرى، زايش، رشد و نمو تا رسيدن به مرحله بلوغ

Fig; 7: Redesigning cycle stages: mating stage, birth, and growth until the maturity 
جدول (: آناليزهاى دستخاهى، اهداف، مشخصات كلى و مراجع استانداردها

Table 1: Analysis, objectives, general specifications and standard references

\begin{tabular}{|c|c|c|c|c|}
\hline $\begin{array}{c}\text { محل انجام آناليز } \\
\text { Laboratory }\end{array}$ & $\begin{array}{c}\text { تجيزات و مدل دستخامها } \\
\text { Model Equipment and } \\
\text { Devices }\end{array}$ & $\begin{array}{c}\text { اهداف آزمون } \\
\text { Analysis purposes }\end{array}$ & $\begin{array}{c}\text { آزمايش موردنظر } \\
\text { Analysis }\end{array}$ & $\begin{array}{l}\text { آزمونها } \\
\text { Exams }\end{array}$ \\
\hline $\begin{array}{c}\text { آزمايشگاه يتروگر افىى دانشكده علوم طبيعى } \\
\text { دانشعاه تبريز } \\
\text { Petrographic } \\
\text { Laboratory, Faculty } \\
\text { of Natural Sciences, } \\
\text { Tabriz University }\end{array}$ & 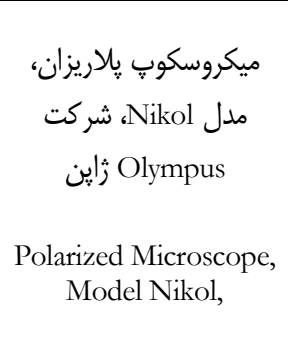 & $\begin{array}{c}\text { شناخت كانىها، بررسى } 1 \text { نويكس سفال، تمبرهاو } \\
\text { مواد افزودنى } \\
\text { Identification of } \\
\text { Minerals, Matrix and } \\
\text { Temper }\end{array}$ & $\begin{array}{c}\text { تِروگرافى } \\
\text { Petrography } \\
\text { (OPM) }\end{array}$ & ساختارشناسى \\
\hline 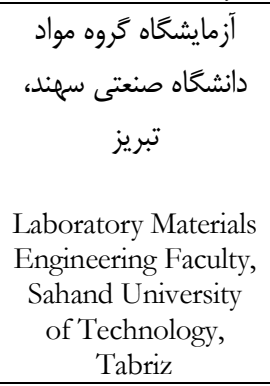 & 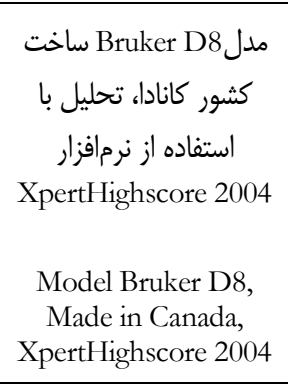 & 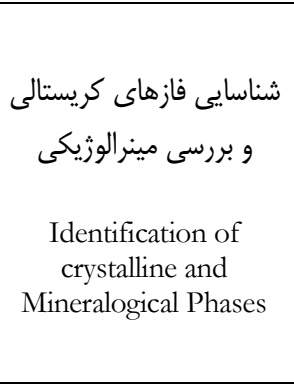 & $\begin{array}{c}\text { يراش يرتوايكس به روش } \\
\text { يودرى } \\
\text { X-ray Powder } \\
\text { Diffraction } \\
\text { (XRPD) }\end{array}$ & Structural \\
\hline 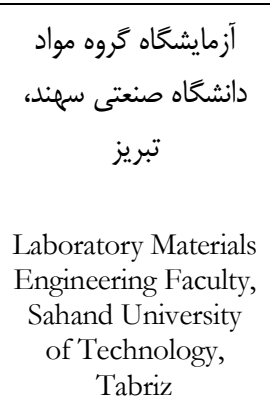 & $\begin{array}{c}\text { مدل } 1 \text { ساخت كشور انخلستان } \\
\text { INCAx- Sight } \\
\text { Model INCAx- Sight, } \\
\text { Made in England }\end{array}$ & 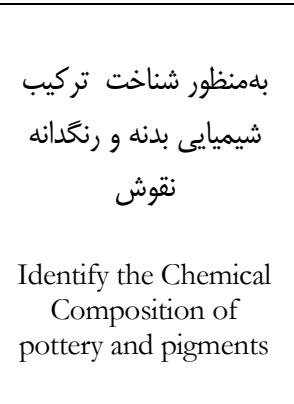 & 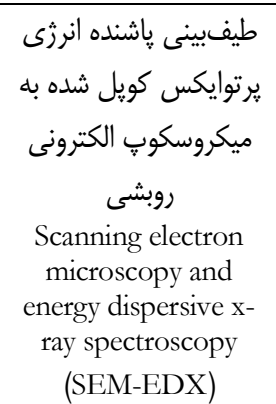 & شناخت تركيب شيميايى \\
\hline
\end{tabular}

مواد سايندهاى همجون اكسيد آلومينيوم جهت رسيدن بـهـ

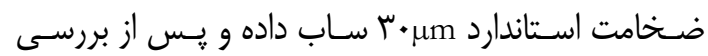

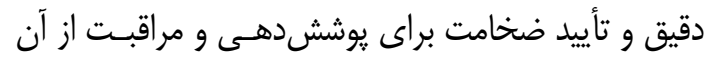

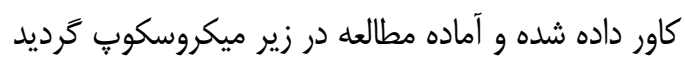

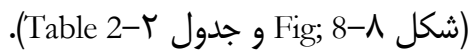

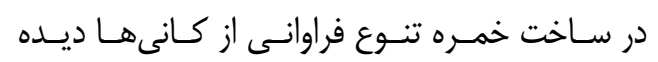

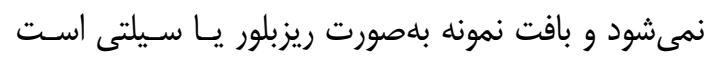

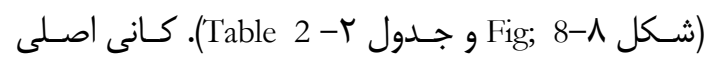
موجود در خمره كانى كوارتز است كه به دو فرم تكبلور و جند بلورى يا ابرى (Cloudy) (Q (Clean))

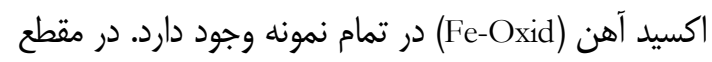

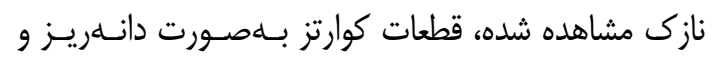
داراى يراكندگى يكدست و همسانى در بافت سفال است،
هـ - نتايج و تحليل مطالعات آزمايشكاهى

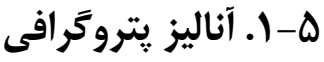
براى شناسايى ساختار و كانىهاى تشكيلدهندهى خمـره، بررسى تركيب، بافت و همجنين تعيـين درجــى حسى حـرارت يخت سفال بر اساس وجود و يا عدم وجود بعضى كانىها،

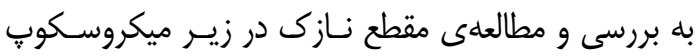

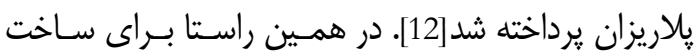

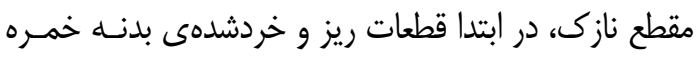

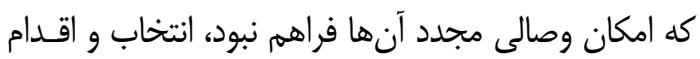

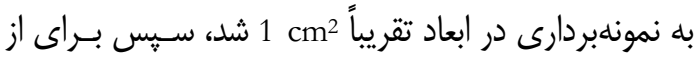

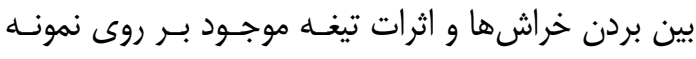

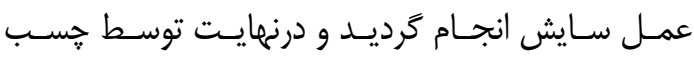

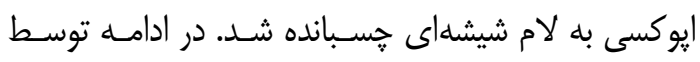



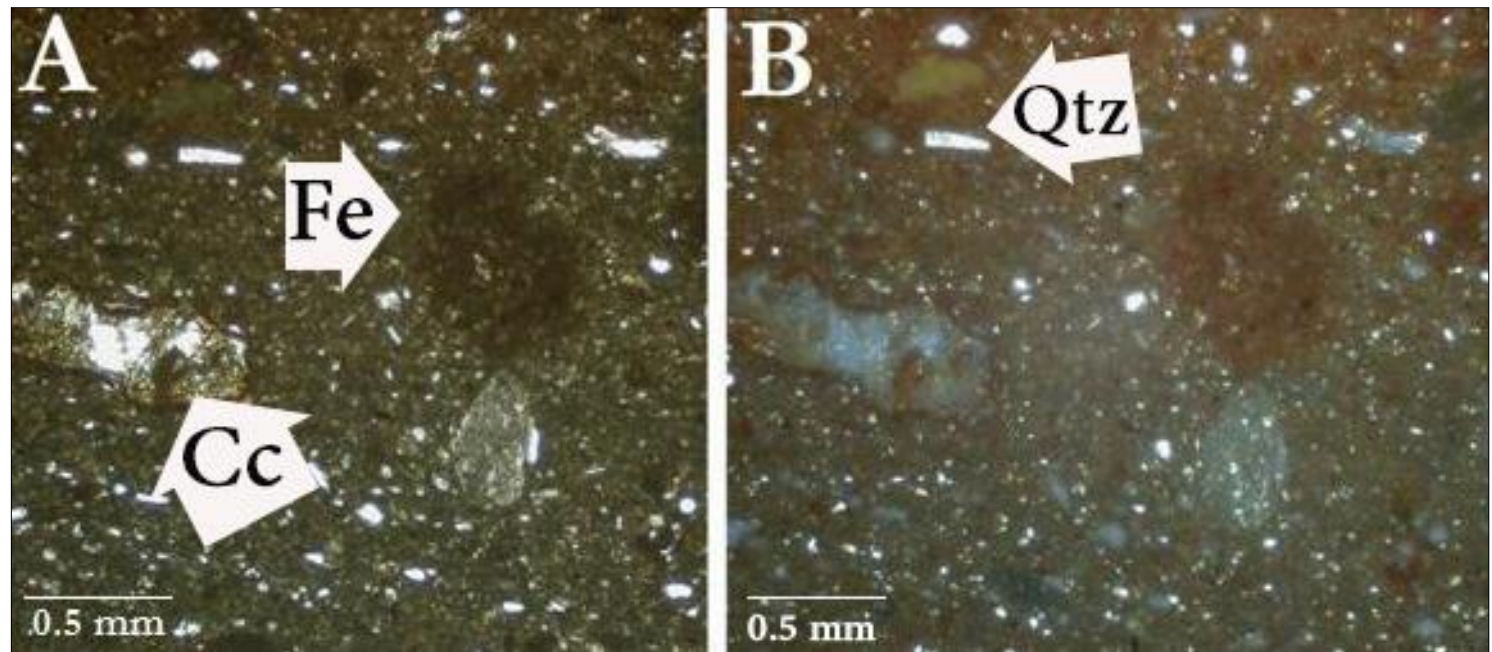

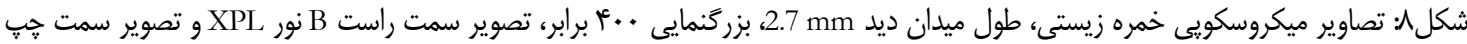

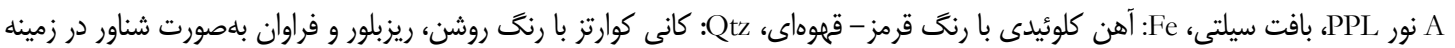
رسى ديده مىشود، Cc: كلسيت ثانويه.

Fig; 8: Micrographe of the Life Cycle Jar, the Length of view field $2.7 \mathrm{~mm}$, magnified 400 times, the right image (B) XPL light and the left image (A) PPL light, silty texture, Fe: Colloid iron with red-browncolor, Qtz: Quartz mineral with bright color, fine and abundant crystal is seen as float in clay, Cc: Secondary calcite.

V V V از بين مىروند، در مطالعه سفال ها بdعنوان شاخص حرارتى در نظـر كرفتـه مسىشـوند[15]. تشـكيل

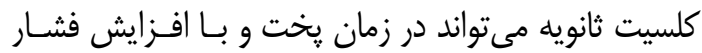
ناشى از حضور CO2 بعد از زمان تجزيه كلسـيت اوليسه و شكل كَيرى آهك آزاد بلهـورت CaO مرور زمان در محيط دفن بر اثر تجزيهى فازهـايى جـون

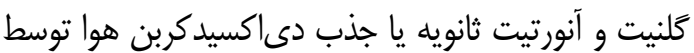

$$
\text { يرتلنديت (Ca(OH)2) رخ دهد [16]. }
$$

درجه حرارت يخت سفال در نمونههاى فاقد كلسـيت

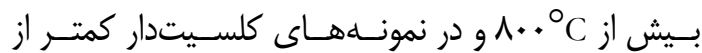

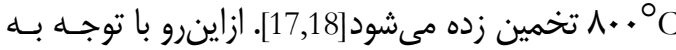
وجود كانى كلسيت در رسوبات منطقه و وجود آن در سفال مورد بررسى مىتوان كفت خمره كشيى احتمـالاً دمـايى دريى

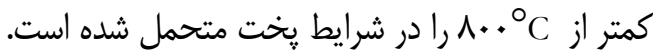

همجنين اين كانىهـا داراى زاويـهـهـاى گَرد و مــدورى

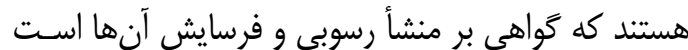

كانى ديخر موجود در نمونه ذرات آهن كلوئيدى است

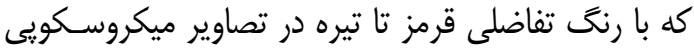
كاملاً مشخص است. همجنين از ديخر اجزاء سـازنده كـهـ ديده مىشود مىتوان به قطعات رسـى يـا سـيلتى اشـاره

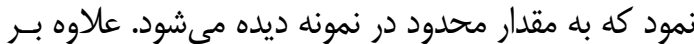
دانههاى يراكنده در بافت سفال در فضاهاى خالى موجـود در اين نمونه مقدار كمى كانى كلسـيت ثانويـه مسىتـوان مشاهده كرد. اين كانى داراى رنغ تفاضلى روشن بـوده و

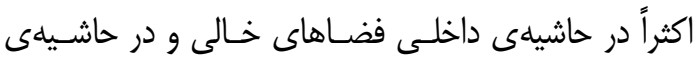
بيرونى سفال ها ديده مىشود. كانى كلسيت و كـانىهـاي

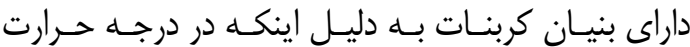

جدول ז: تركيب ساختارى خمره بر اساس آناليز يتروًّافى، در اين جدول خمره منسوب زيستى با كد KSH1 نامكذارى شده است.

Table2. Structural composition of the Life Cycle Jar (here designated as Sample KSH1) based on petrographic analysis

\begin{tabular}{|c|c|c|c|c|c|c|}
\hline Sample No. & Qtz (Clean) & Qtz (Cloudy) & Grog & Fe-oxid & Cc & Texture \\
\hline KSH1 & $*$ & $*$ & $*$ & $*$ & $*$ & Fine \\
\hline
\end{tabular}


Counts

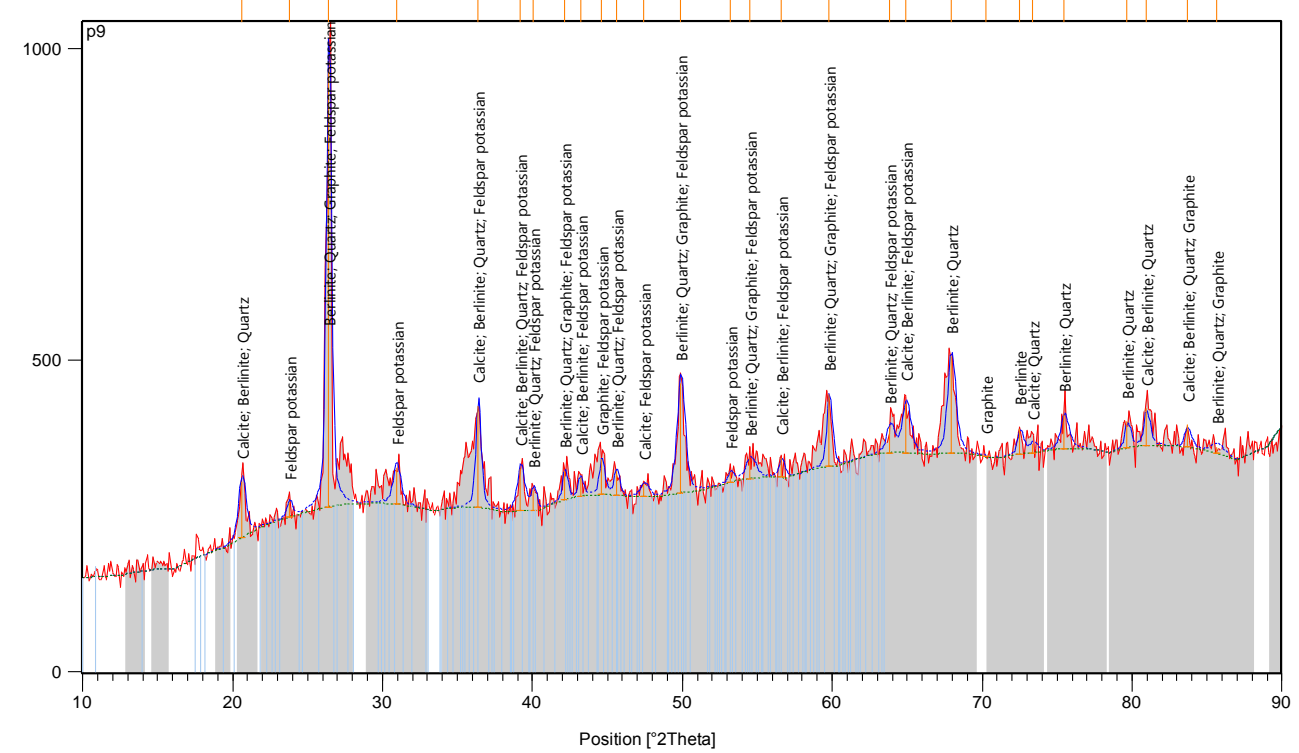

شكلج: دياكرام XRPD نمونه مورد نظر، نشاندهندهى فازهاى كوارتز، كرافيت، برلينيت، كلسيت و فلدسيار پِتاسيم است.

Fig; 9: XRPD Diagram of desired Sample Represents the Quartz, Graphite, Berlinite, Calcite and PotassiumFeldspar phases.

شناسايى شده در سفال، كانى كوارتز است كـه البتـهـ در

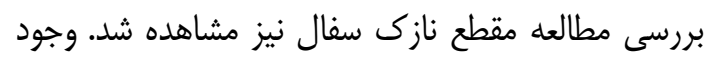

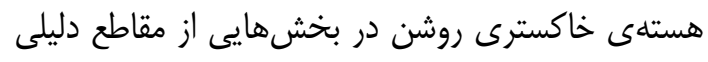

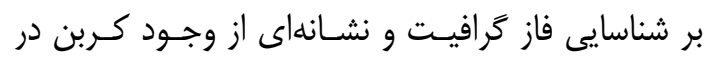

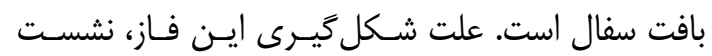

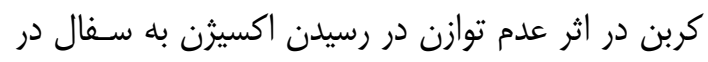

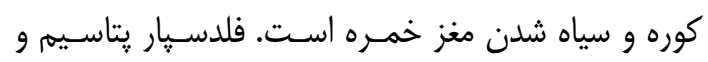

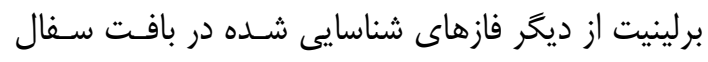

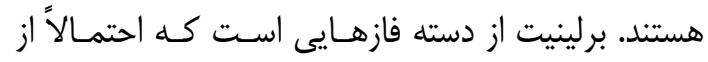

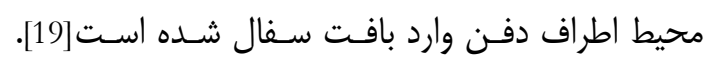

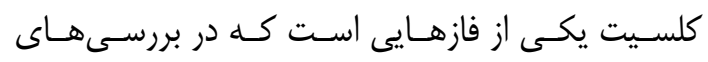

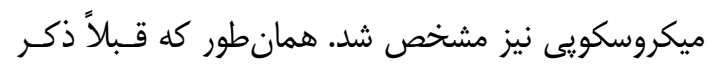

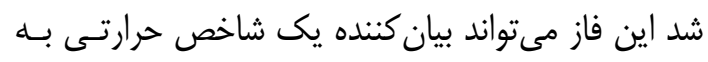

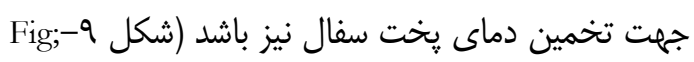

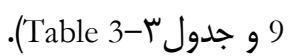

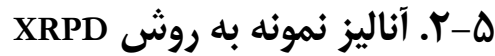
جهت شناسايى و تشخيص فازهاى كريسـتالى موجـود در

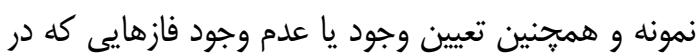

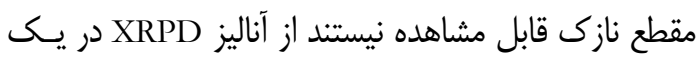

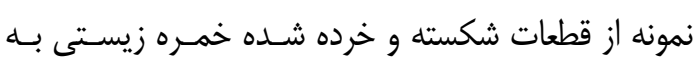

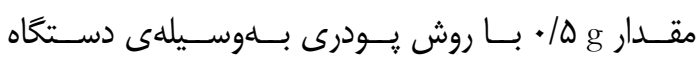

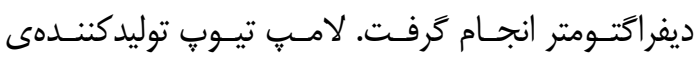

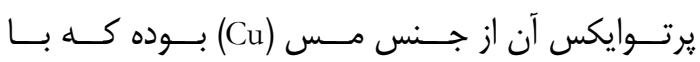

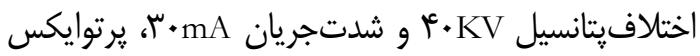

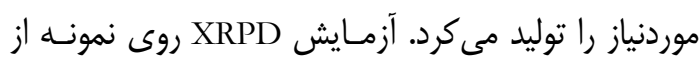

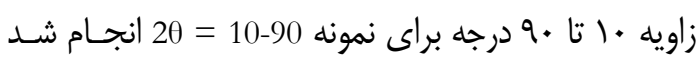

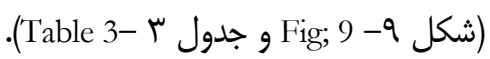
با توجه به طيف آناليز XRPD در نمونه مورد نظـر،

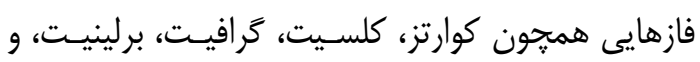

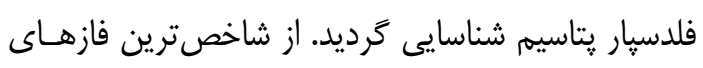

Xدول سا: فازهاى كريستالين شناسايى شده در آناليز XRPD

Table 3: Crystalline phases identified in the XRPD analysis

\begin{tabular}{|c|c|c|c|}
\hline No. & Compound Name & Chemical Formula & Ref. Code \\
\hline 1 & Calcite & $\mathrm{CaCO}_{3}$ & $00-003-0593$ \\
\hline 2 & Berlinite & $\mathrm{AlPO}_{4}$ & $01-071-1043$ \\
\hline 3 & Quartz & $\mathrm{SiO}_{2}$ & $01-085-0504$ \\
\hline 4 & Graphite & $\mathrm{C}$ & $01-075-1621$ \\
\hline 5 & Feldspar potassian & $\mathrm{K}_{5} \mathrm{Na}_{5} \mathrm{AlSi}_{3} \mathrm{O}_{8}$ & $01-084-0710$ \\
\hline
\end{tabular}


جدول ثٔ: نتايج تركيب شيميايى بدنه خمره با استفاده از آناليز SEM-EDX

Table 4: Chemical composition of the vessel's body by SEM-EDX analysis

\begin{tabular}{|c|c|c|c|c|c|c|c|c|c|c|c|c|}
\hline ELT & $\mathrm{CO}_{2}$ & $\mathrm{SiO}_{2}$ & $\mathrm{Al}_{2} \mathrm{O}_{3}$ & $\mathrm{Fe}_{2} \mathrm{O}_{3}$ & $\mathrm{MgO}$ & $\mathrm{CaO}$ & $\mathrm{Na}_{2} \mathrm{O}$ & $\mathrm{K}_{2} \mathrm{O}$ & $\mathrm{MnO}$ & $\mathrm{P}_{2} \mathrm{O}_{5}$ & $\mathrm{Cl}$ & $\mathrm{PbO}$ \\
\hline$\% \mathrm{~W}$ & 42.08 & 29.01 & 13.83 & 2.11 & 5.70 & 1.13 & 2.71 & 2.18 & 0.09 & 0.31 & 0.38 & 0.40 \\
\hline
\end{tabular}

سرتاسر دنيا و همجنين در تمامى دورههاى تاريخى يافت آن

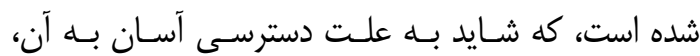

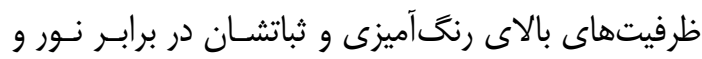

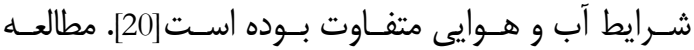

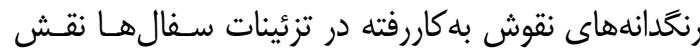
بسيار مهمى را در مطالعات باستانشناسى ايفا مى كند، بــهـ

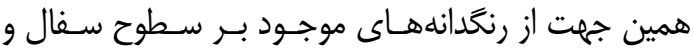
نقوش آنها به جهت شناخت و درى بهتر، آناليز عنصـرى ردئ كرفته شد. بيشترين عناصر شناسايى شده در رنـــهـاى خمـره

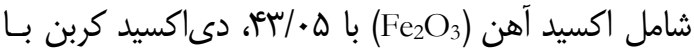

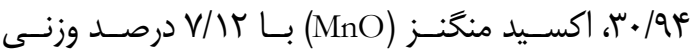

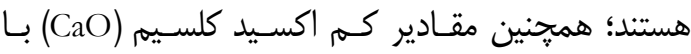

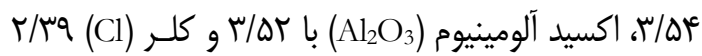
درصد وزنى است. اكسيدهاى آهن عموماً بيشترين كاربرد را در استفاده بلعنوان رنخدانه داشته است. اين رنخدانههـا بلهور طبيعى و باصورت فرمهاى متفاوت در تمام مناطق

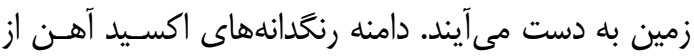

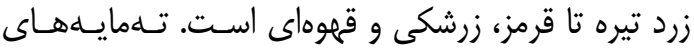

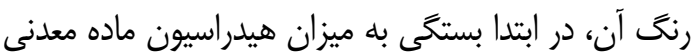
و همجِنين به ميزان اندازه ذرات، شـكل و تركيسب آن بـانـا ديخـر مـواد معـدنى بسـتخى دارد. همجنــين آنيدراسـيون اكسيدهاى آهن هماند $\mathrm{Fe}_{2} \mathrm{O}_{3} \mathrm{O}_{3}$

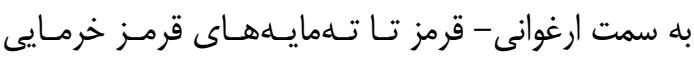
مى شود. همجنين هيدراته شدن اكسيدهاى آهن (همانــــ (Fe باعث تمايل ييدا كردن رنخ آن به سـمت آهـ

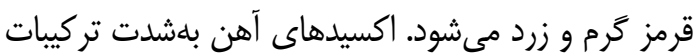
קايدارى در مقابل مواد اسيدى، قليايى (ضعيف تا متوسـطا) و همجينين تابش نور هستند. شواهد اثبات نموده است كه

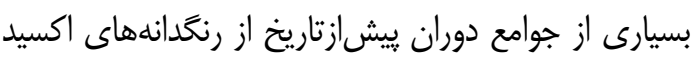

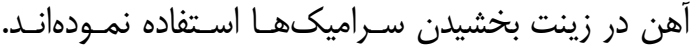

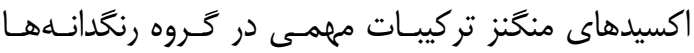

\section{ه-" آ. آناليز نمونه به روش SEM-EDX}

شناسايى تركيبات شيميايى و عناصر موجود در بدنه خمره

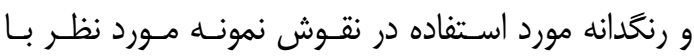

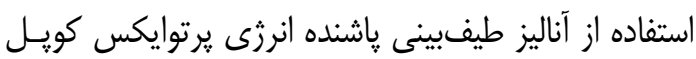

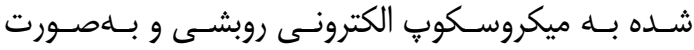
نقطهاى صورت كرفت. تركيبات شناسايىشده بـراى بلنــه

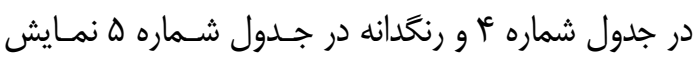

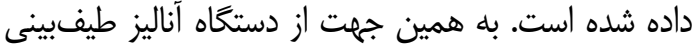

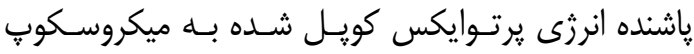
الكترونى روبشى استفاده شد، ايـن دستـاه داراى فيلمـان

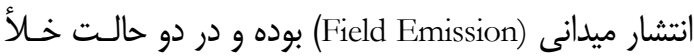

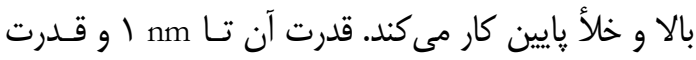

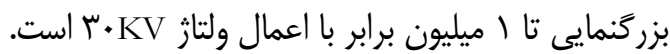

ه-ب-1. نتايج آناليز بدنه خمره نمونهبردارى به جهـت انجـام آنـاليز فـوق از مغـز ســال

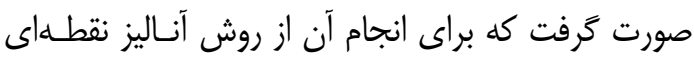

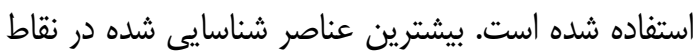

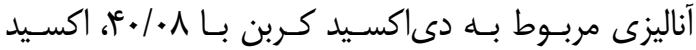
سيليسيم سه/ץا درصد وزنى است، همجنين مقادير اكسيد منيـزيم

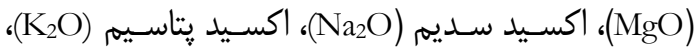
اكسيد آهن (

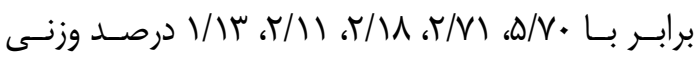
است. با توجه به عناصر مشخصه بدنه خمره مىتـوان بــهـ ساختار رسى آن بيى برد. همجنين عناصر شناسـايى شـده

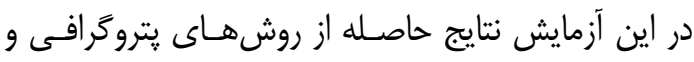

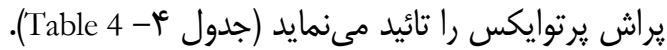

ه-r-r. نتايج آناليز رنكَدانه نقوش

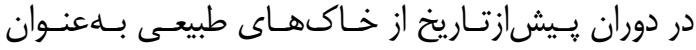

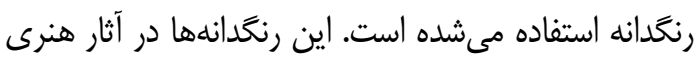


جدول ه: تركيب شيميايى رنخدانه به كار رفته در نقوش خمره

Table 5: Chemical composition of the pigments used in the painted designs of the jar

\begin{tabular}{|c|c|c|c|c|c|c|c|c|c|c|c|}
\hline $\mathrm{ELT}$ & $\mathrm{CO}_{2}$ & $\mathrm{Al}_{2} \mathrm{O}_{3}$ & $\mathrm{Fe}_{2} \mathrm{O}_{3}$ & $\mathrm{MgO}$ & $\mathrm{CaO}$ & $\mathrm{Na}_{2} \mathrm{O}$ & $\mathrm{K}_{2} \mathrm{O}$ & $\mathrm{MnO}$ & $\mathrm{P}_{2} \mathrm{O}_{5}$ & $\mathrm{Cl}$ & $\mathrm{PbO}$ \\
\hline$\% \mathrm{~W}$ & 30.94 & 3.52 & 43.05 & 0.61 & 3.54 & 0.1 & 0.85 & 7.12 & 0.05 & 2.39 & 0.58 \\
\hline
\end{tabular}

اين كانىها بلهوسيلهى آناليز XRD مورد تأييـد و تصـديق

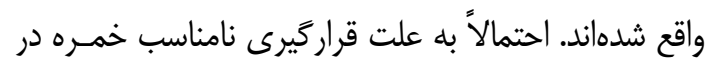

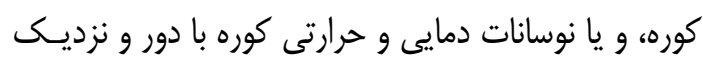

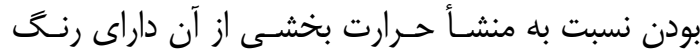

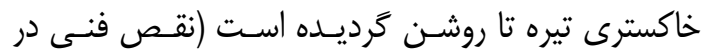

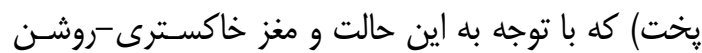
سفال مىتوان مشاهده كرد، اين حالت را در بررسى آنـاليز

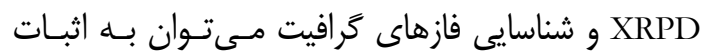

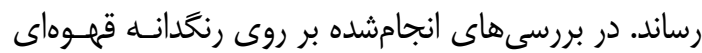

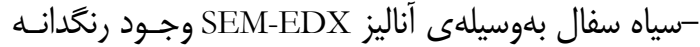

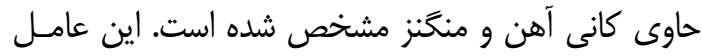
نشان از بهكاركيرى مواد معدنى إيايدار در ايجاد نقوش تيره

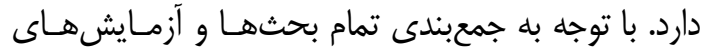

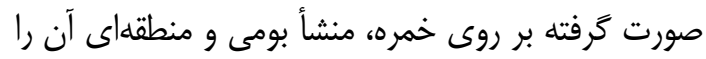

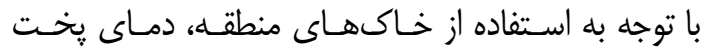

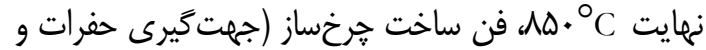

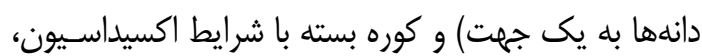
و بهكار كَيرى رنخدانههاى معدنى آهن (هماتيت) و منگَنـز

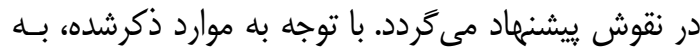

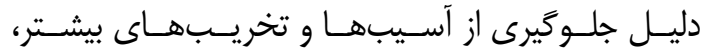
اولويتدهى روشهاى درمـانى ييشــيرانه و حفـاظتى بـا توجه به شناخت ساختارى خمره ييشنهاد مىشود.

\section{سياسگزارى}

بدينوسيله نغارندكان لازم مى دانند از تمـامى كاركنـان

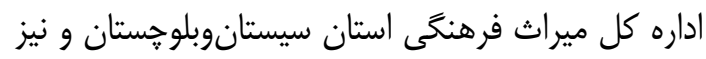

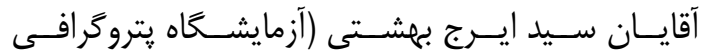

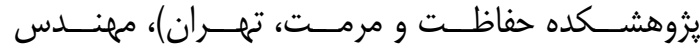

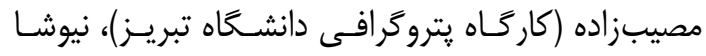

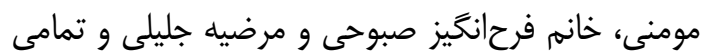

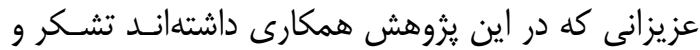
قدردانى نمايند.
بشمار مىروند كه دامنهاى از قهوماى مايل به زرد تا سـياه

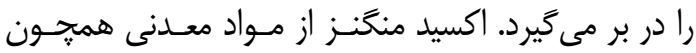

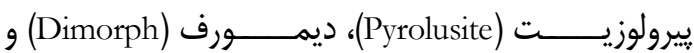
رامســليت (Ramsdellite) ( همجنين اين رنخدانهها در تزئين بسيارى از سـالينههـاى

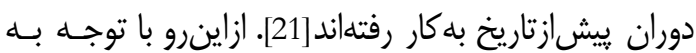

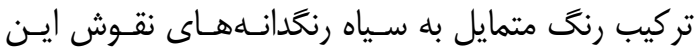

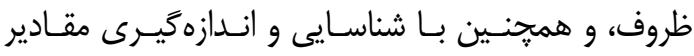
عناصر آن، كه اكسيد آهن بيشترين ميزان و اكسيد منخنز

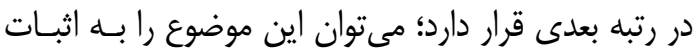
رساند كه پايهى رنغ نقوش سفال، اكسيد آهن به همـراه

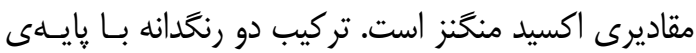

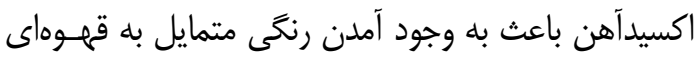
تيره تا سياه مىشود (جدول ه- 5 - Table).

\section{V. نتيجه كيرى و ييشنهادها}

با توجه به شاخص بودن و اهميت خمره سـفالى ترخـهـي حيات، واقع در موزه جنوب شرق كشـور (مـوزه زاهــدان)،

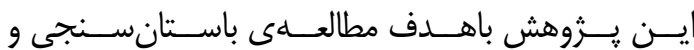
ساختارشناسى ظـــف مـوردنظر در جهـت دسـتيابى بـهـ اطلاعات فنى (ميزان حرارت، فن ساخت و شـرايط كـوره)

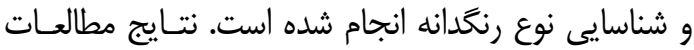

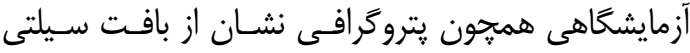

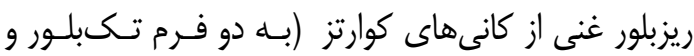

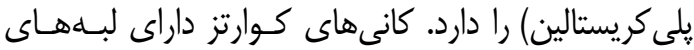

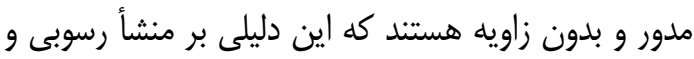

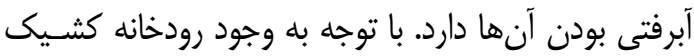

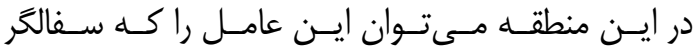
ييشازتاريخى از خاكهاى منطقهاى آبرفتى رودخانه براى

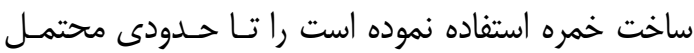
دانست. از اجزاء ديخر مشاهدهشده در مقطع نازك قطعـات كراق، اكسيدهاى آهن و كلسيت ثانويه هستند كه تمامى

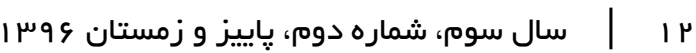




\section{Reference}

[1] Heydari M. Reporting speculation and organizing Keshik cemetery of Nikshahr city. Zahedan: Administration of cultural heritage, handicrafts and tourism organization of Sistan and Baluchistan [unpublished report]; 2013.[in Persian]

$$
\text { ]حيدرى محمد. گزارش گمانهزنى و ساماندهى گورستان }
$$

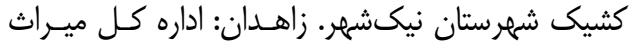

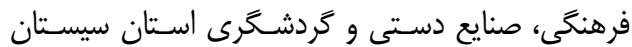

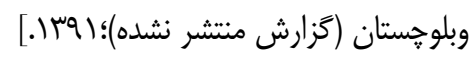

[2] Dehghan S. Exploring the role of Antelopes in artworks of ancient [Unpublished M.A thesis]. Islamic Azad University, Department of archaeology, central Tehran Branch, Iran, 2011. [in Persian]

] دهقان ساناز. بررسى نقش بزكوهى در آثار هنرى ايـران

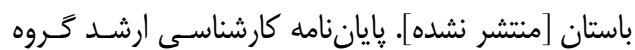

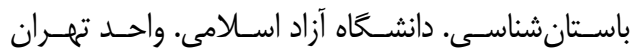

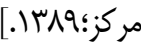

[3] Afzaltousi E. Rug the preserver of wild goat figure since the ancient times. J Negareh 2013;31:55-67. [in Persian]

[افضل طوسى عفتالسادات. كليم حافظ نغاره بزكـوهى

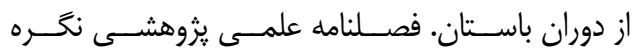

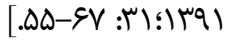

[4] Hatam G. The role and symbolism in ancient potteries of Iran. Art Mag 1996;24:355-78. [in Persian]

[حاتم غلامعلى. نقش و نماد در سفالينهاى كهن ايران.

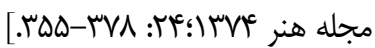

[5] Sarraf MR. Kidin Hutran bronze cup from Arjan Behbahan. Journal of Asar 1991;17:4061. [in Persian]

[صراف محمد رحيه. جام برنزى كيدين هوتران مكشوفه

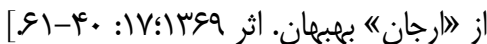

[6] Sedghi Y. Pathology, technology, conservation and restoration potteries of Keshik cemetery in Nikshahr, Balouchistan. [Unpublished B. A. thesis]. University of Zabol, Department of Restoration of Monuments. Iran, 2014. [in Persian]

] صدقى ياسين. آسيبشناسـ، فـنشناسـى، حفاظـت و

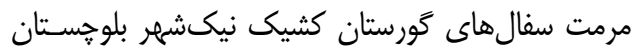

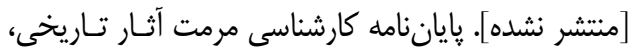

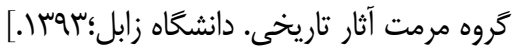

[7] Sedghi Y. Conservation and restoration measures of discovered potteries from Keshik cemetery in Nikshahr, Balouchistan. Journal of Kav, cultural heritage administration handicrafts and tourism organization of Sistan and Baluchestan 2016;2:12-5. [in Persian]
[صدقى ياسين. اقدامات حفاظتى و مرمتى سفالينههـاى

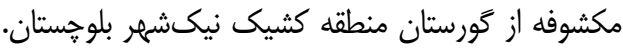

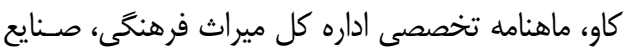

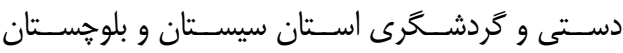

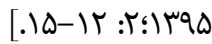

[8] Talai H. The bronze age of Iran. Tehran: SAMT; 2012. [in Persian]

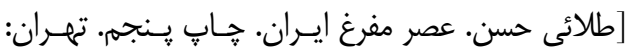

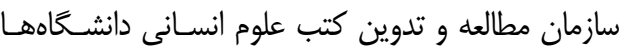

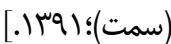

[9] Stein A, Andrews FH, Hobson RL. Archaeological reconnaissances in northwestern India and south-eastern Iran. Macmillan; 1937.

[10] S-Sajjadi SM. Eight Speech: Archeology and History of Balouchistan. Cultural heritage organization, Iran; 1996. [in Persian]

[سيدسجادى سيدمنصور. هشت كفتار: باسـتانشناسـى و

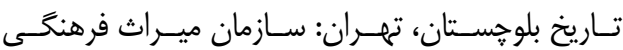

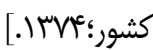

[11] Iran $G$ organization and mineral explorations of. Geological map of 1:2500000 Nikshahrcity. Tehran: Offest; 1989. [in Persian]

[سازمان زمين شناسى و اكتشافات معـدنى كثـور. نقشـــ

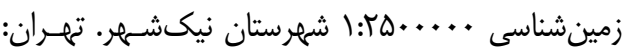

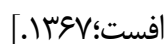

[12] Quinn PS. Ceramic petrography: the interpretation of archaeological pottery \& related artefacts in thin section. Archaeopress; 2013.

[13] Riederer J. Thin section microscopy applied to the study of archaeological ceramics. Hyperfine Interact 2004;154:143-58. doi:https://doi.org/ 10.1023/B:HYPE.0000032029.24557.b1.

[14] Reedy CL. Thin-section petrography of stone and ceramic cultural materials. Archetype; 2008.

[15] Betancourt PP, Peterson SE. Thin-section Petrography of ceramic materials. Institute for aegean Prehistory, archaeological excavation manual 2009;2.

[16] Noghani S, Emami SM. Secondary Calcite in texture of pottery from Persepolis, Iran, Florida: 38th international symposium in archaeometry, Florida, U.S.A. in Press; 2010;3:15-34. [in Persian]

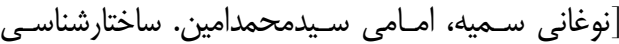

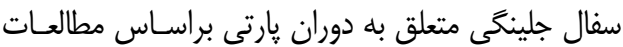

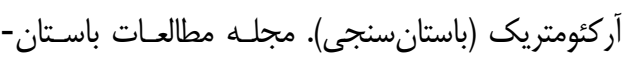

$$
\begin{aligned}
& \text { شناسى • وس إ؛ }
\end{aligned}
$$

[17] Emami SM, Trettin R. Phase generating 
processes in ancient ceramic matrices through microstructure investigation with high resolution microscopy methods. Journal of Advanced Microscopy Research 2010;5:181-9. doi: https://doi.org/10.1166/jamr.2010.1040

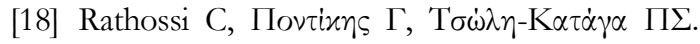
Mineralogical differences between ancient sherds and experimental ceramics: indices for firing conditions and post-burial alteration.

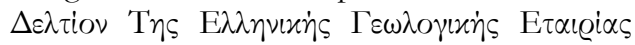
2010;43:856-65.

[19] Emami SMA, AriyaNasab S, Ahmadi H, AChavordi A, F-Kaliri P. Archaeology methods for structuralogy of discovered bricks from brick walls of Takhte- Jamshid. Journal of Archaeological Studies 2015;6:1-19. [in Persian]

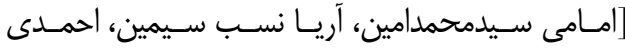

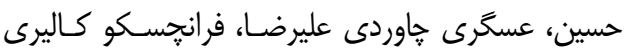

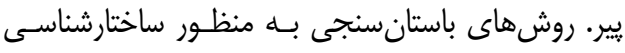

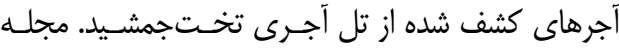

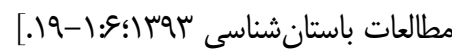

[20] Darchuk L, Tsybrii Z, Worobiec A, Vázquez C, Palacios OM, Stefaniak EA, et al. Argentinean prehistoric pigments' study by combined SEM/EDX and molecular spectroscopy. Spectrochim Acta Part A Mol Biomol Spectrosc 2010;75:1398-402. doi: https://doi.org/10.1016/j.saa.2010.01.006

[21] Rapp G. Archaeomineralogy (Natural Science in Archaeology) 2009. 


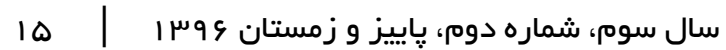

